\title{
Capital Regulation and Systemic Risk in the Insurance Sector
}

\author{
Thomas Gehrig (University of Vienna, CEPR, ECGI, SCR, VGSF)* \\ Maria Chiara Iannino (University of St Andrews) ${ }^{\dagger}$
}

25 November $2017^{\ddagger}$

\begin{abstract}
This paper analyses systemic risk in and the effect of capital regulation on the European insurance sector. In particular, the evolution of an exposure measure (SRISK) and a contribution measure (Delta CoVaR) are analyzed from 1985 to 2016 . With the help of multivariate regressions the main drivers of systemic risk are identified. The paper finds an increasing degree of interconnectedness between banks and insurance that correlates with systemic risk exposure. Interconnectedness peaks during periods of crisis but has a long-term influence also during normal times. Moreover, the paper finds that the insurance sector was greatly affected by spillovers from the process of capital regulation in banking. While European insurance companies initially at the start of the Basel process of capital regulation were well capitalized according to the SRISK measure, they started to become capital deficient after the implementation of the model-based approach in banking with increasing speed thereafter.

These findings are highly relevant for the ongoing global process of capital regulation in the insurance sector and potential reforms of Solvency II. Systemic risk is a leading threat to the stability of the global financial system and keeping it under control is a main challenge for policy makers and supervisors. This paper provides novel tools for supervisors to monitor risk exposures in the insurance sector while taking into account systemic feedback from the financial system and the banking sector in particular. These tools also allow an evidence based policy evaluation of regulatory measures such as Solvency II.
\end{abstract}

JEL classification: B26, E63, F65, G22, G28, H12, N24;

Keywords: capital shortfall, insurance sector, systemic risk, interconnectedness between banks and insurance

${ }^{*}$ University of Vienna, Department of Finance, Oskar-Morgenstern Platz 1, Vienna.

$\dagger$ University of St Andrews, School of Economics and Finance, Castlecliffe, The Scores, KY16 9AR, St Andrews, UK.

${ }^{\ddagger}$ We are grateful for the comments of Charles Calomiris, Robert Engle, Andreas Grünbichler, Martin Hellwig, and Clas Wihlborg. 


\section{Introduction}

With the Great Financial Crisis the resiliency of the financial sector overall has become a topic of major interest. Many discussions have focused on the systemic contribution of banks, identifying and tightening the capital requirements for the most systemic institutions. Only a few contributions, however, have looked into the insurance sector, even despite the fact that in the great financial crisis of 2007-08 one of the first institutions in need of bailout has been the systemically important insurance group AIG. ${ }^{1}$

Therefore, it has become a first-order priority to understand not only how insurance companies contribute to systemic risk of the overall financial sector, but also when and why they have increased their systemic exposure and their systemic contribution. The literature identifies the main drivers of risk in the growth of non-traditional funding and non-traditional investment activities (Cummins and Weiss, 2014, Weiss and Mühlnickel, 2014) ${ }^{2}$. Moreover, insurance companies and banks are becoming more and more interconnected (Cummins, Wei and Xie, 2011, Chen, Cummins, Viswanatha, Weiss, 2013, Billio, Getmansky, Lo, Pelizzon, 2012) as the insurers business models are rapidly changing, and their returns are comoving more with banks returns.

We start estimating the evolution of systemic risk for the European insurance companies over the past three decades. In a sample of European insurance companies, we measure systemic risk as the expected capital shortfall conditional on the overall equity market being in severe distress (Brownlees and Engle, 2017) and we observe that insurers are growing in systemic exposure since the beginning of the 2000s, and the level of exposure is not decreasing, but reaching new highs since then.

Moreover, when comparing the evolution of insurance companies SRISK with the other subsectors, we observe that banks still are the major contributors on average, though the new peak in insurers' risk in 2016 should raise serious concerns about the stability of the European financial sector as a whole. Therefore, we study the drivers of such increase in systemic exposure in order to understand better the nature of the structural change that we observe especially since 2002.

In earlier work, we have investigated the impact of Basel regulation on the financial sector and on the European banks in particular (Gehrig, Iannino, 2017). However, regulators, as well as researchers, have so far largely ignored the effect of changing business models that could transfer part of the systemic risk exposure from the banking sector to other financial areas, in particular to the insurance. Is the witnessed increase in systemic risk in the insurance sector due to insurance companies effectively taking over banking related business such as long-term lending and infrastructure investments? Is it an implication of regu-

\footnotetext{
${ }^{1}$ For example, the Financial Crisis Inquiry Report states that "enormous sales of credit default swaps were made without putting up initial collateral, setting aside capital reserves, or hedging its exposure, a profound failure in corporate governance, particularly its riskmanagement practices" (Phil Angelides, 2011).

${ }^{2}$ See Eling and Pankoke (2016) for a review of the literature.
} 
latory arbitrage? It is of great interest to understand this potentially divergent effect of the Basel measures on individual bank risk (microprudential risk) vs. aggregate systemic risk in other financial sectors (spillover of systemic risk).

There has been a long discussion on the need for insurance regulation (Harrington, 2009, Acharya and Richardson, 2014, Baranoff, 2012) since the Great Crisis. In 2016, the IFM reported "The contribution of life insurers to systemic risk has increased in recent years [...] Supervisors and regulators should take a more macroprudential approach to the sector [...] it includes the international adoption of capital and transparency standards for the sector." The process ended in the regulatory framework, known as Solvency II and applicable since 1 January 2016, that binds insurance companies in a way very similar in spirit to the Basel regulation binds banks.

Solvency II parallels the Basel regulation in at least two aspects: capital requirements and internal models. With the objective of increasing risk awareness and competitiveness, Solvency II states the requirements of holding "enough" capital to cover a larger range of risks than traditional insurance risks. The capital needs can be quantified by the insurance company with either standardized formulas or using internal models under supervisory approval.

Having seen the unintended effects of banking regulations on the business models and incentives of banks, the urgent question arises about similar unintended errors in the insurance industry. Moreover, as we demonstrate, insurance business models have already been deeply affected by banking regulation and the induced substitution of banking activities by the insurance sector especially in the area of long-term financing.

In terms of descriptive analysis, our main finding is the observation of a significant increase in conditional capital shortfall in the insurance industry starting in 2002. We also observe strong increases in interconnectedness, particularly in the years 2007 and 2011. This applies to several measures of interconnectedness and appears relatively robust in this sense.

As to the drivers of the build-up in systemic risk in the insurance sector and its interconnectedness, we identify essentially the same drivers as in the banking sector. However, typically banks lead insurance, though we can assess the contribution of different regulatory regimes on systemic risk exposure when we distinguish different sub-periods. Importantly, we find that only starting with 2016, lead-lag relations between banks and insurance tend to reverse, such that systemic risk exposure in insurance starts leading systemic risk exposures in banks. This evidence relies on a relatively short period of observations but is statistically significant.

Our findings accord well with a recent Worldbank study by Malik and Xu (2017). They find similar patterns of interconnectedness in a global sample of systemically important banks and insurance companies as we find for a large European sample of stock-listed banks and insurance companies including nonsystemically important ones. While these authors study various measures of interconnectedness, they also find a close correlation of their indicators with the systemic risk exposure measure SRISK on which our study is based.

A possible explanation which is consistent with the above evidence is capital 
arbitrage between banks and insurance sectors that have increased the riskiness of banks business models. Koijen and Yogo (2016) find that circumventing capital requirements is a major motive for life insurance companies to establish captives in the US markets. This tendency started in early 2000 due to changes in capital regulation of US insurance companies. While captives are not subject to risk-based capital regulation, the risk is not transferred to investors outside the financial group. Therefore this behaviour is leading to capital shortfall in the overall group.

The paper is organized as follows: Section 2 presents the data. Section 3 provides a descriptive analysis of various systemic risk measures for the recent three decades. Section 4 develops measures of interconnectedness and presents their historical evolution. Section 5 introduces some methodology that is required for the analytical analysis of the systemic risk drivers in section 6 . Section 7 concludes with final remarks.

\section{Data}

In order to investigate the evolution of systemic risk in the different financial sectors, we start with collecting data for European institutions from 1996 to 2016. Micro data on financial institutions are extracted from Compustat Global and SNL. Table 2 reports the composition of our overall sample, and we can identify institutions as (1) 195 commercial banks, (2) 215 diversified institutions, (3) 77 insurance companies and (4) 115 real estates companies. ${ }^{3}$

For the inference section and computation of the interconnectedness measures, we exclude the real estate firms and focus our analysis on banks, diversified institutions and insurance companies only. We also select the largest institutions, belonging to the second and first quintiles of market capitalization in each sub-sector.

In particular, the sample of insurers consists of 4 Insurance Brokers, 22 Life \& Health Insurance, 35 Multi-line Insurance, 10 Property \& Casualty Insurance, and 6 Reinsurance companies.

Table 2 presents the distribution of our insurance companies across 15 countries from the Euro-area, Switzerland and the United Kingdom ${ }^{4}$. We use quarterly fundamental (balance sheet) data as well as daily market prices and capitalization in order to estimate market measures of systemic risk.

Finally, we collect macro economic data from Datastream and the ECB database.

\footnotetext{
${ }^{3}$ Due to a reclassification in the Compustat database in 2003 , there is not a clear distinction between the bank institutions in groups 1 and 2, therefore in the inference analysis we will consider a single group for banks or diversified financial services.

${ }^{4}$ We include active as well as non-active institutions, for whom we have at least 10 years of balance sheet data.
} 
Table 1: Subsectors in the European sample

\begin{tabular}{lrr}
\hline Subsectors & Frequency & $\%$ \\
\hline Banks (before 2003)/Diversified Banks (after 2003) & 144 & 23.92 \\
Regional Banks (from 2003) & 35 & 5.81 \\
Thrifts \& Mortgage Finance (from 2003) & 16 & 2.66 \\
\hline (1) Commercial banks & 195 & 32.39 \\
& & \\
Diversified Financial Services (prior 2003), Other Diversified (after 2003) & 31 & 5.15 \\
Multi-Sector Holdings & 19 & 3.16 \\
Specialized Finance & 16 & 2.66 \\
Consumer Finance & 8 & 1 \\
Asset Management \& Custody Banks & 97 & 16.11 \\
Investment Banking \& Brokerage & 32 & 5.32 \\
Diversified Capital Markets & 7 & 1.16 \\
Others & 5 & 0.83 \\
\hline (2) Diversified financial services & 215 & 35.71 \\
& & \\
Insurance Brokers & 4 & 0.66 \\
Life \& Health Insurance & 22 & 3.65 \\
Multi-line Insurance & 35 & 5.81 \\
Property \& Casualty Insurance & 10 & 1.66 \\
Reinsurance & 6 & 1 \\
\hline (3) Insurance companies & 77 & 12.79 \\
Diversified REITs & & \\
Industrial REITs & 9 & 1 \\
Office REITs & 1 & 0.17 \\
Retail REITs & 9 & 1.5 \\
Real Estate Management \& Development & 3 \\
Real Estate Operating Companies & 0.5 \\
Real Estate Development & 20 \\
Real Estate Services & 3.32 \\
\hline (4) Real Estates Companies & 18 \\
\hline a This table reports the frequency of different institutional types in our sample. The categories are iden- \\
tified by Compustat Global, as (i) commercial banks or diversified institutions, (ii) diversified financials, \\
(iii) insurance companies, and (iv) real estates companies. & 2.99 \\
& 1.83 \\
\hline
\end{tabular}


Table 2: Sample by country

\begin{tabular}{lrr}
\hline Country & Frequency & \multicolumn{1}{l}{$\%$} \\
\hline GBR & 139 & 23.09 \\
DEU & 87 & 14.45 \\
FRA & 80 & 13.29 \\
ITA & 73 & 12.13 \\
CHE & 59 & 9.8 \\
ESP & 37 & 6.15 \\
NLD & 25 & 4.15 \\
GRC & 23 & 3.82 \\
BEL & 20 & 3.32 \\
AUT & 18 & 2.99 \\
LUX & 13 & 2.16 \\
IRL & 11 & 1.83 \\
FIN & 7 & 1.16 \\
PRT & 6 & 1 \\
CYP & 4 & 0.66 \\
\hline Total & 602 & \\
\hline
\end{tabular}

a This table reports the frequency of firms in each country in our sample.

\section{Evolution of Systemic Risk Measures from 1985- 2015}

How did systemic risk measures evolve for European financial institutions during the past 3 decades?

We start our analysis by constructing various risk measures such as marginal expected shortfall (MES), conditional capital shortfall or SRISK (Brownless and Engle, 2017), and $\triangle C o V a R$ (Adrian and Brunnermeier, 2016) at the level of the individual institutions. We present their evolution over thirty years as well as their relation to measures of systematic risk.

\subsection{SRISK}

The first step is the estimation of the measures of systemic risk. Brownlees and Engle (2017) define systemic risk exposure as the capital shortfall of an institution when the whole financial sector is in distress. To be clear, systemic risk is intended to measure systemic feedback and, typically, amplification of individual risk.

In order to define the systemic risk measures assume a bivariate daily time series model of the equity returns of institution $i$, dependent on a value-weighted market index $m$ that we proxy with the MSCI Europe index. Volatilities are estimated with an asymmetric GJR GARCH process (Glosten, Jagananthan and Runkle, 1993) and correlations with a DCC correlation model (Engle, 2002).

We evaluate measures of daily performance in the event of an extreme aggregate shock, as the daily market index falls more than its $95 \%$ VaR. The expected daily loss of the bank returns in this case is the Marginal Expected Shortfall 
(MES):

$$
M E S_{i t}(c)=E_{t-1}\left(r_{i t} \mid r_{m t}<c=q_{5 \%}\right)
$$

The equity loss in a six-month horizon, the Long-Run Marginal Expected Shortfall (LRMES), is approximated to $1-e^{(\log (1-d) * b e t a)}$, where $\mathrm{d}$ is the $40 \%$ six-month crisis threshold for the market index decline, and beta is the dynamic market beta. ${ }^{5}$

Finally, we combine the market information above with the current equity market value and the outstanding book value of debt. We determine the expected capital shortfall (SRISK) that an institution would experience in case of distress as:

$$
\begin{aligned}
S_{R I S K_{i, t}} & =E_{t-1}[\text { Capital shortfall } \mid \text { Crisis }] \\
& =E_{t-1}[k(\text { Debt }+ \text { Equity }- \text { Equity } \mid \text { Crisis }] \\
& =E_{t-1}\left[k\left(\text { Debt }_{i, t}\right)+(1-k)\left(1-\text { LRMES }_{i, t}\right) \text { Equity }_{i, t} \mid \text { Crisis } \ 2\right)
\end{aligned}
$$

where: $k$ is the prudential capital ratio, that we assume $8 \%$.

The time evolution of our systemic risk measures seem to exhibit quite different patterns across sector and between banks and insurance companies in particular.

Figure 1 presents the evolution of the average conditional capital shortfall measure SRISK for different types of financial institutions from 1988-2016. As it becomes immediately evident from this graph, positive capital shortfall has not been an issue in the insurance industry until about 2002. It did increase soon and already in the period from 2004-2008 the average systemic risk exposure per institution was identical to that of banks. While the systemic risk exposure per institution did not explode as much as for banks, it has been on an upward trajectory since 2002. So according to the conditional capital shortfall measure SRISK exposure to systemic risk has become a real concern with increasing importance in the insurance sector since 2002. This date appears closely related to the modifications of specific insurance regulations in 2002, like directive 2002/83/EG for life insurance and 2002/13/EG for property insurance preparing the road towards risk based supervision. Accordingly, it will be important to analyze the drivers of the systemic risk measures, which we will do below in Section 6.

\section{$3.2 \Delta C o V a R$}

Turning to another widely used systemic risk measure $\Delta C o V a R$ (Figure 2) a different picture emerges.

$\triangle C o V a R$ has been developed by Adrian and Brunnermeier (2016). While SRISK focuses on the capital needs of an institutions in case of market distress CoVaR focuses more on the interconnection between institutions and the

\footnotetext{
${ }^{5}$ We also use a previous approximation as $L R M E S=1-e^{(-18 * M E S)}$, such as Acharya, Engle and Richardson (2012). It represents the equity value loss over a six-month period conditional on a market fall by more than $40 \%$ within the next six months.
} 


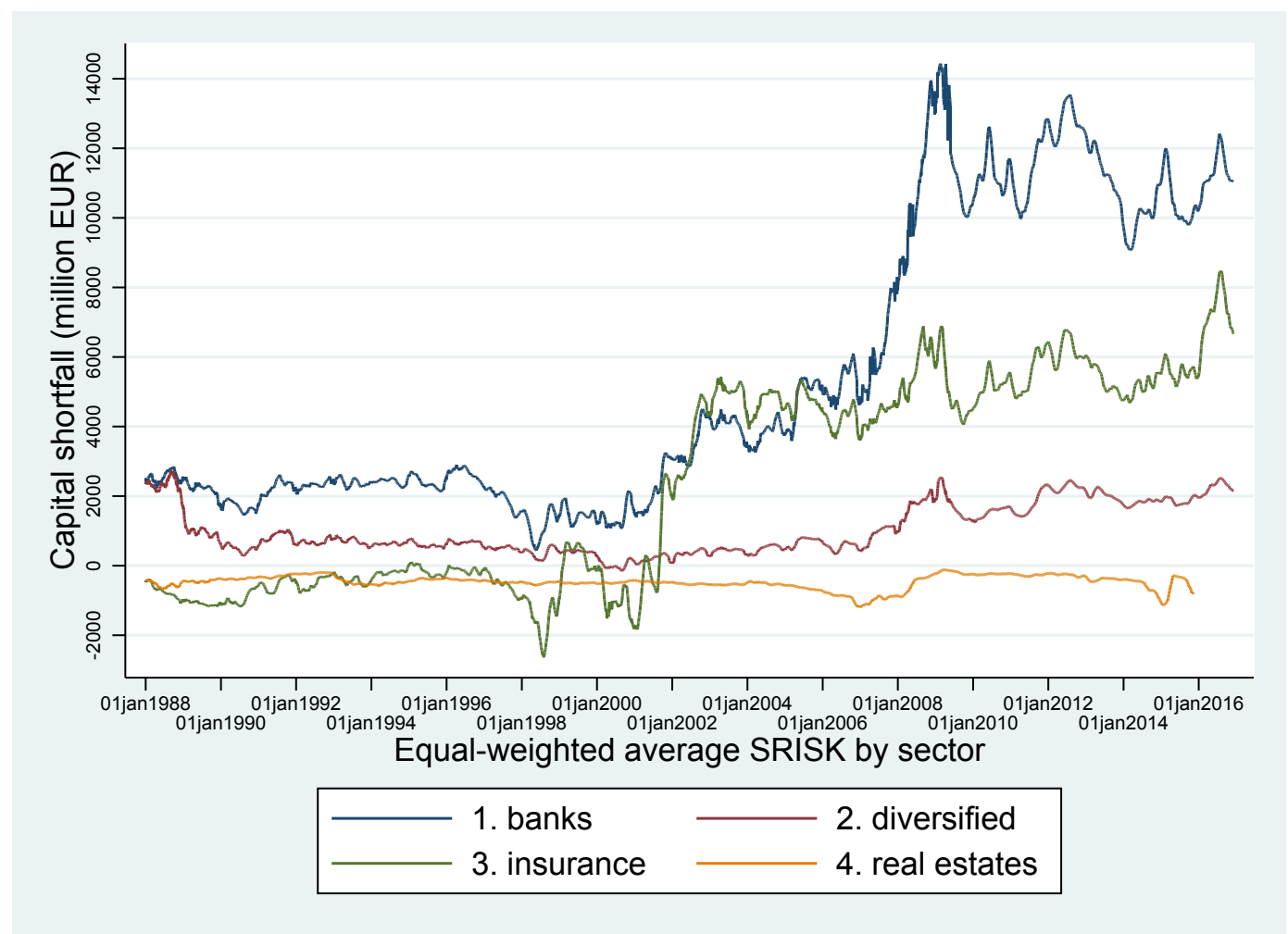

Figure 1: Evolution of systemic risk - SRISK. The Figure reports the evolution of the average daily estimated SRISK for the four sub-sectors of the European financial system. The SRISK is estimated by MLE using a GJR-DCC Garch model, as Equation 2. It represents the average daily capital shortfall/surplus of each group, as banks (1), diversified financials (2), insurance companies (3) and real estate companies (4). 
possible contagion to the whole sector. It only requires market data and it corresponds to the extreme market loss conditional on extreme losses on the returns of an institution i. The marginal contribution of firm i to the overall systemic risk, $\Delta \mathrm{CoVaR}$, is the difference between the CoVaR in distress and the $\mathrm{CoVaR}$ in a median state.

We estimate an aggregate extreme loss as its $\alpha \%$-Value-at-Risk, the maximum loss of the market return within the $\alpha \%$-confidence interval, conditionally on some event $C\left(r_{i} t\right)$ observed for institution i:

$$
\operatorname{Pr}\left(r_{m t} \leq \operatorname{CoVaR} R_{t}^{m \mid C\left(r_{i t}\right)}\right)=\alpha
$$

Using a quantile regression approach, we identify this distress event of firm i as a loss equal to the $(1-\alpha) \%$ VaR of firm i: $r_{i t}=V a R_{i t}(\alpha)$.

The systemic risk of the bank $\mathrm{i}$ is then defined as the difference between the $\mathrm{CoVaR}$ of the financial system conditional on firm i being in distress and the $\mathrm{CoVaR}$ of the financial system conditional on firm i being in its median state:

$$
\left.\Delta \operatorname{CoVaR} R_{i t}(\alpha)=\operatorname{CoVaR} R_{t}^{m \mid r_{i t}=\left(\operatorname{VaR}_{i t}(\alpha)\right)}-\operatorname{CoVaR} R_{t}^{m \mid r_{i t}=\operatorname{Median}\left(r_{i t}\right)}\right)
$$

Turning our attention now on the evolution of the contribution measure $\triangle C o V A R$ (Figure 2) a different picture emerges relative to the exposure measure SRISK. Again the trajectories differ across sectors but not dramatically so. In fact there is much more commonality in the sense that they seem to peak in the same periods. While there does not seem to be a general trend upwards towards increased contribution to systemic risk a moderating long-term effect induced by prudential regulation such as Basel I and II and Solvency I cannot be observed either.

\subsection{Systematic Risk}

Finally, let us check the evolution of market risk as proxied by beta. We estimate the market beta from a GJR-DCC Garch model between the firm stock returns and the MSCI Europe index.

Figure 3 establishes that market beta had been quite volatile for insurance as well as banking. We observe that till 2007-08, banks and insurers' beta tend to move quite similarly. However, there are also significant differences between the insurance and the banking sector thereafter. The average beta of insurance companies tends to trend down towards the end of the observation period, while we see a volatile but uptrend upwards for banks.

\subsection{Summary}

By way of summarizing, we observe an increasing build-up of systemic risk in the insurance sector. This can already be seen in the summary statistics of Table 3, establishing that the insurance sector has already become comparably 


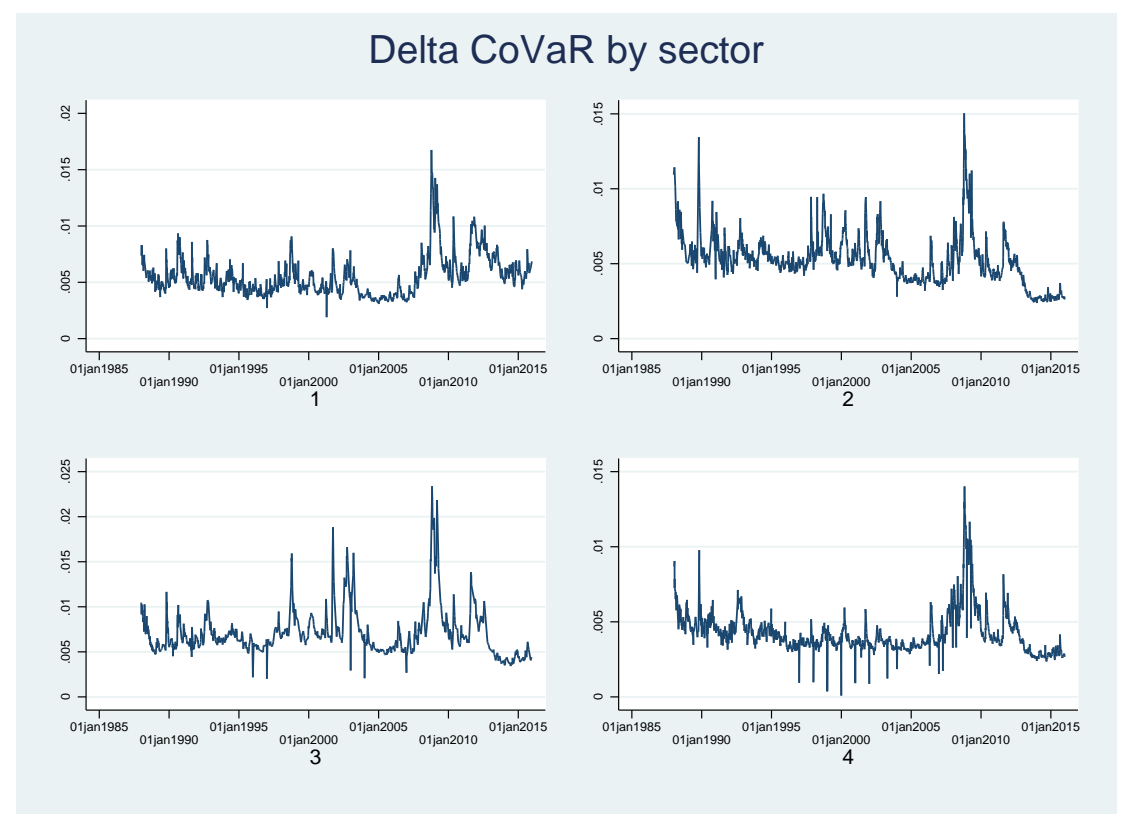

Figure 2: Evolution of systemic risk - Delta CoVaR. The Figure reports the evolution of the daily estimated Delta CoVaR in Equation 4. We report banks (1), diversified financials (2), insurance companies (3) and real estates (4).

systemically important as the banking sector according to a wide range of systemic risk measures. While insurance with an exposure of 2.249 bill. EUR is second in terms of conditional capital shortfall (SRISK) only to banks, in terms of $\triangle \mathrm{CoVaR}$ and MES the insurance sector even dominates the banking sector.

It is useful to distinguish between the two main systemic risk measures in terms of the different aspects of systemic risk they are intended to measure. SRISK is a conditional shortfall measure, and, hence, measures the exposure of a financial institution with respect to market stress. As such it is an exposure measure of systemic risk. CoVaR on the other hand is a measure of contagion, since it provides a measure of how stress of an individual institution is transmitted to other institutions. Accordingly, Delta CoVaR can be usefully interpreted as a contribution measure to systemic risk.

Finally we should stress that in the implementation of Basel regulations as well as Solvency II typically different holding periods are considered for which exposures, or value-at-risk, are measured. This might seem to imply that we should use different parameter choices for our systemic risk measures in the banking and the insurance sector. Without denying the differential supervisory treatment across industry sectors, we deliberately stay away from measuring systemic risk differentially across industry sectors. In fact, we assume that the underlying economics does not change by differential administrative procedures. We can easily modify our risk measures according to whatever supervisory procedure is recommended. By treating banks and insurance equally we can unveil 

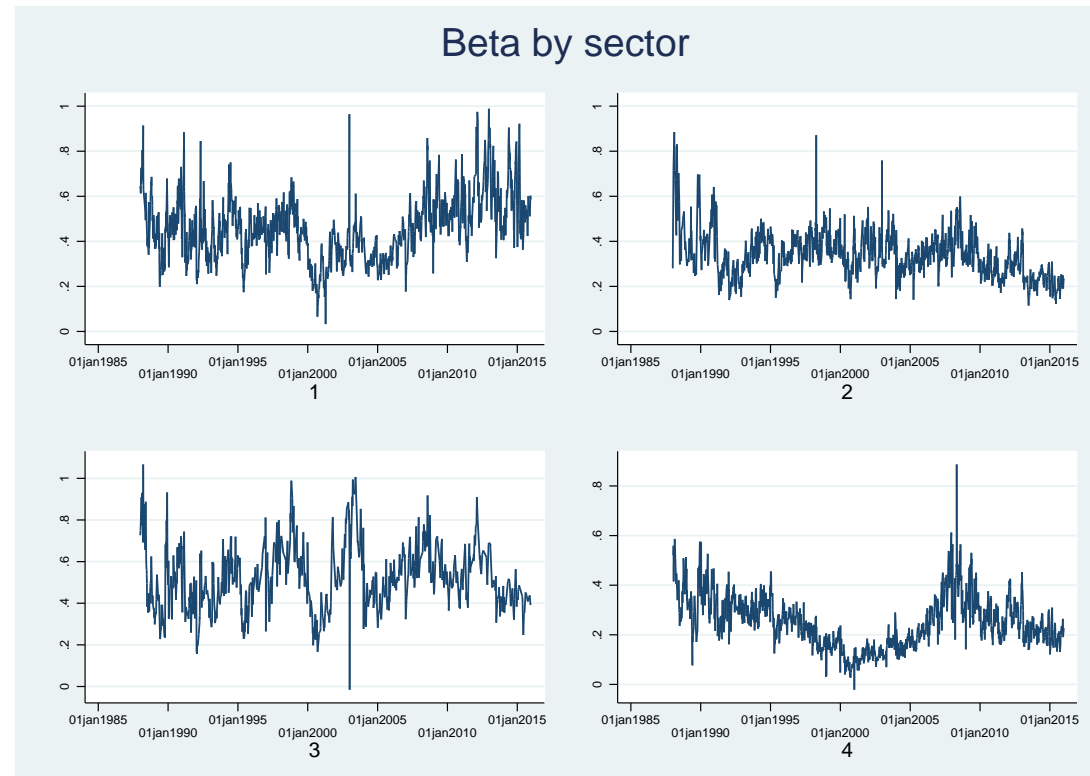

Figure 3: Cross-sector variation of systematic risk. The Figure presents the evolution of the daily beta by different country, across time, from January 1987 to 2015 . We report banks (1), diversified financials (2), insurance companies (3) and real estates (4). It represents the sensitivity of the bank equity returns to the MSCI Europe index returns. It is estimated by a GJR DCC Garch model. 
potentially unintended economic spill-overs more easily, which might be masked by differential supervisory treatment. Accordingly, for the sake of consistency and comparability in calculating SRISK, we follow the parameter choices of Brownless and Engle (2017) for the banking sector.

Table 3: Descriptive Statistics by Financial Sector

\begin{tabular}{lrrrrrrrr}
\hline Sector & Market Value & Total Assets & SRISK & $\Delta$ CoVaR & MES & \multicolumn{1}{l}{ Beta } & M-t-B & Zscore \\
\hline Banks & 6978.926 & 144901.1 & 6915.287 & 0.006845 & 0.016158 & 0.660389 & 4.131728 & 31.91816 \\
Diversified & 1151.392 & 18810.37 & 714.1439 & 0.005827 & 0.014671 & 0.527122 & 2.237037 & 3545.546 \\
Insurance & 5597.102 & 73985.83 & 2249.562 & 0.007391 & 0.016825 & 0.693799 & 3.633783 & 17.9186 \\
Real Estates & 470.9905 & 1146.032 & -312.352 & 0.003577 & 0.010485 & 0.411477 & 1.973271 & 23.73448 \\
\hline Total & 3208.856 & 57416.29 & 2412.573 & 0.006022 & 0.014817 & 0.570628 & 2.908429 & 1899.054 \\
\hline
\end{tabular}

a This table reports the mean statistics of our main variables of interest, aggregated by sectors: commercial banks (1), diversified financials (2), insurance companies (3) and real estates (4). We report Market capitalization, total assets, SRISK, Delta CoVaR, Marginal Expected Shortfall, market beta, Market-to-Book, and Zscore of default.

\section{Interconnectedness between Banks and Insur- ance Companies}

Given the dramatic increase in the capital shortfall measure in the insurance sector, the question arises to what extent this could be related to the close relations between insurance and banking firms. It might be that particularly the shortfall measure reflects the close ties between the business models of insurance companies and banks. In order to address this issue we develop a measure of interconnectedness between the insurance and the banking sector.

Following Billio et al (2012), we measure connections as significant Granger causalities in pairwise bank-insurance comparisons. For each pair of insurance company and banks, we run a vector-autoregression (VAR) model on average weekly returns of bank $\mathrm{i}$ and insurer $\mathrm{j}$ :

$$
\begin{aligned}
R_{i t} & =\alpha_{i}+\sum_{s}^{S} \gamma_{i s} R_{t-s}^{i}+\sum_{s}^{S} \beta_{j s} R_{t-s}^{j}+\varepsilon_{t} \\
R_{j t} & =a_{j}+\sum_{s}^{S} \lambda_{j s} R_{t-s}^{j}+\sum_{s}^{S} b_{i s} R_{t-s}^{i}+\xi_{t}
\end{aligned}
$$

We determine the optimal number of lags according to the Aikaike information criterion, and perform the VAR whenever there is at least one optimal lag. Moreover, we can assign the direction of a connection, identifying either the bank $\mathrm{i}$ or the insurance company $\mathrm{j}$ as the leader. We perform a Granger causality test after each regression, and we classify the pair as a connection if either $\mathrm{j}$ Granger-causes $\mathrm{i}$ if $\beta$ is significant, or vice-versa $\mathrm{i}$ Granger-causes $\mathrm{j}$ if $\mathrm{b}$ is significant.

While Billio et al. (2012) concentrate on return-spillovers at the mean returns, we extend their methodology to include tail properties. Hence, we can 
better account for spill-overs in tail events such as crises phenomena. Therefore we estimate lead-lag patterns in their Marginal Expected Shortfalls (MES) between banks and insurance companies to identify connections that might only arise in periods of critical market conditions. In order to do this we estimate pairwise VARs on the MES of each bank/insurer pair and consider the number of significant Granger causality connections as above.

For purposes of comparison we estimate the level of connectedness between each pair of banks and insurers, as the number of significant relations that an institution has with firms of the other group, both for the mean returns as well as the marginal expected shortfalls.

Here we contribute an interesting and novel observation: The evolution of our connectedness measure is consistent with a general rise in the level of interconnectedness in the financial system. As we see in Figure 4, insurance companies have tended to be more and more connected with banks since the end of 1990s according to both measures, based on mean return and based on MES. This interconnectedness appears to have evolved symmetrically from insurance companies to banks and vice versa. However, consistent with prior work this increase does not appear particularly impressive. Only when spill-overs in the tail are considered according to our MES-based measure, this relation becomes much stronger. Moreover, it becomes apparent that the interconnectedness became much stronger during crises-periods. So the interactions between insurers and banks intensify particularly during periods of market stress. This observation is new and not available in pure mean spill-overs such as analyzed by Billio et al. (2012) and others.

Moreover, we document cyclical patterns in virtually all of our interconnectedness measures. Interconnectedness was relatively low in 2005 and then again in 2012.

A priori it is not clear, whether this increase in interconnections adds to resiliency or to turmoil in unstable times. Do the interconnections help to better diversify, and thus moderate risk, or will they contribute to amplify negative shocks within the whole financial system? In our Section 6 we will address this issue by measuring the impact of our interconnectedness measure on systemic risk exposure. Before we do this multivariate analysis, the next section will prepare methodological issues. 


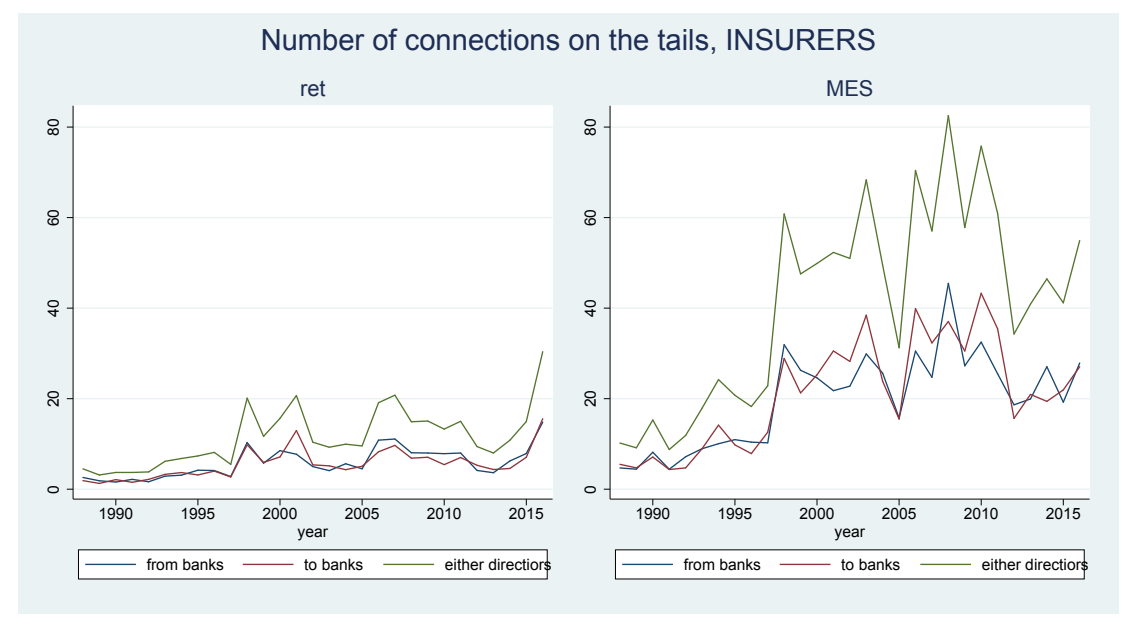

Figure 4: Evolution of the Interconnectedness of Banks and Insurers. The Figure presents the evolution of the number of connections between insurance companies and banks. We show the connections in which insurers are leading (to banks), connections in which banks are leading (from banks) and the overall number (either directions).

\section{Methodology}

Before conducting the multivariate analysis, some methodological preparations are required and presented in this section. In the first subsection we analyze dynamical interaction between our systemic risk measure. We then introduce a measure of market mis-valuation for individual companies that will turn out useful as a driver of systemic risk. Finally we set up the multivariate regressions.

\subsection{Comovements in the Systemic Risk Measures}

We perform a VAR model on the aggregate system to measure lead-lag effects in the previous main variables, market beta, Delta CoVaR and first difference in SRISK. We run VAR models on sector averages of the banking system i and the insurance system $\mathrm{j}$, for lags $\mathrm{s}=0$ to $\mathrm{S}$, the optimal lag length according to the Akaiki information criterion:

$$
\begin{aligned}
\Delta S R I S K_{i t} & =\alpha_{i}+\sum_{s}^{S} \gamma_{i s} \Delta S R I S K_{t-s}^{i}+\sum_{s}^{S} \beta_{j s} \Delta S R I S K_{t-s}^{j}+\varepsilon_{t} \\
\Delta S R I S K_{j t} & =a_{j}+\sum_{s}^{S} \lambda_{j s} \Delta S R I S K_{t-s}^{j}+\sum_{s}^{S} b_{i s} \Delta S R I S K_{t-s}^{i}+\xi_{t}
\end{aligned}
$$

We perform a Granger causality test after each regression, and we classify the pair as a connection if either $\mathrm{j}$ Granger-causes $\mathrm{i}$ if $\beta$ is significant, or vice-versa $\mathrm{i}$ Granger-causes $\mathrm{j}$ if $\mathrm{b}$ is significant. 


\subsection{Market Mispricing}

Market-based risk measures are often challenged by their dependence on market prices. For example, regulators often refer to market-to-book anomalies as indications of market irrationality or, at least, market distortions or mis-pricing. In order to deal with this potential problem we also provide an attempt to deal with potential mispricing. Therefore, we also estimate such misvaluation decomposing the book-to-market into its mispricing component and its growth opportunity component, based on the theoretical contribution of Rhodes-Kropf, Robinson and Viswanathan (2004).

Rhodes-Kropf, Robinson and Viswanathan (2004, 2005) break the marketto-book ratio into three components: firm-specific deviations from valuation relative to its contemporaneous peers (FSE), time-series sector deviation from the long-run accounting multiples (TSSE), and long-run value-to-book, as proxy for growth opportunities (LRVTB).

The log market-to-book ratio can then be decomposed as:

$$
\begin{aligned}
m_{i t}-b_{i t} & =\underbrace{\left(m_{i t}-v\left(B V_{i t}, \alpha_{j t}\right)\right)}_{\text {firm-specific error }}+ \\
& +\underbrace{\left(v\left(B V_{i t}, \alpha_{j t}\right)-v\left(B V_{i t}, \overline{\alpha_{j}}\right)\right)}_{\text {time series sector error }}+\underbrace{\left(v\left(B V_{i t}, \overline{\alpha_{j}}-b_{b_{i t}}\right)\right.}_{\text {growth option }}
\end{aligned}
$$

We proceed estimating cross-sectional regressions of market value of bank/insurer $\mathrm{i}$ on its book value, by sector $\mathrm{j}$ and week $\mathrm{t}$, such as:

$$
\ln (M V)_{i t}=\alpha_{j t}+\beta_{j t} \ln (B V)_{i t}+\varepsilon_{i t}
$$

Therefore, we predict the value of the institution i, as:

$$
\begin{aligned}
\left.v\left(B V_{i t}, \alpha_{j t}\right)\right) & =\widehat{\alpha_{j t}}+\widehat{\beta_{j t}} \ln (B V)_{i t} \\
v\left(B V_{i t}, \overline{\alpha_{j}}\right) & =\overline{\alpha_{j}}+\overline{\beta_{j}} \ln (B V)_{i t} \\
\overline{\alpha_{j}} & =\sum_{t=1}^{T} \widehat{\alpha_{j t}}
\end{aligned}
$$

and predict the misvaluation component as:

$$
\begin{aligned}
\text { Misv } & =F S E+T S S E \\
& =m_{i t}-v\left(B V_{i t}, \overline{\alpha_{j}}\right)
\end{aligned}
$$

The evolution of mispricing across sectors can be seen in Figure 5. According to this measure the occurrence of mispricings was quite different across financial sectors. There was significant underpricing in banking during the dot.com bubbles while insurance was over-priced according to this measure. Both measures, however, seem to agree that mispricings have receded significantly both in banking and in insurance after 2010. 


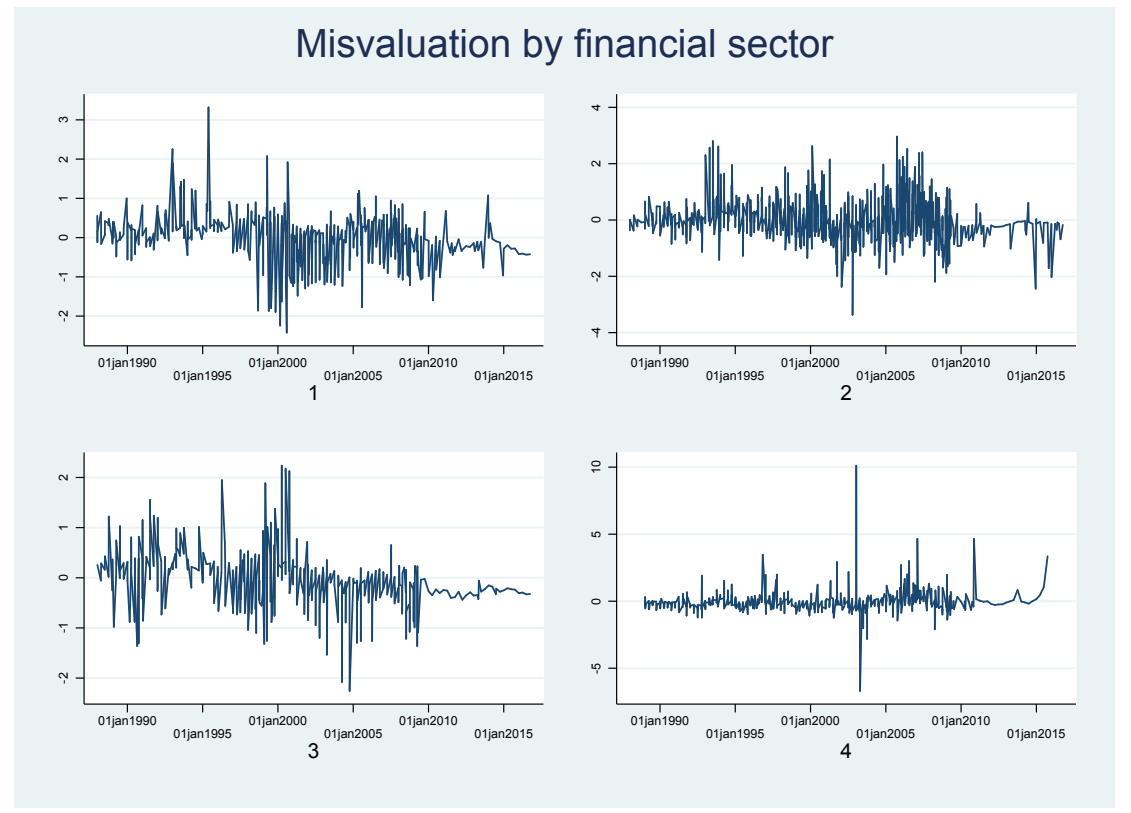

Figure 5: Evolution of Misvaluation component of Book-to-Market. The Figure reports the evolution of the weekly estimated misvaluation in Equation 14. We report banks (1), diversified financials (2), insurance companies (3) and real estates (4).

\subsection{Multivariate Analysis}

In the next step, we focus on bank-level data. We analyze the drivers of the SRISK measures, particularly focusing on the spillovers between banks and insurance companies, on a subsample of 173 banks and 29 insurers with available data.

In earlier work (Gehrig, Iannino, 2017), we identified market beta, CISS measure of market stress, Z-score measure of default, market return and longterm interest rate, market capitalization and leverage as important explanatory variables for the accumulation of capital shortfall in the European banking system.

We use a dynamic specification where we first detrend SRISK from its first lag, and then regress it using fixed effects panel regressions. ${ }^{6}$ For robustness, we also show results using an IV estimator, where we instrument the first lag of SRISK with its third lag. We control for the above set of variables $X_{k q-1}$, measured one week back, and include the misvaluation component (Misv) and the number of significant connections $\left(N C o n n_{r e t}\right.$ or $\left.N C o n n_{M E S}\right)$ as described

\footnotetext{
${ }^{6}$ We also try a dynamic OLS fixed effects panel regressions, as the long time dimension of our sample should mitigate the typical endogeneity issue.
} 
in the previous section:

$$
\begin{aligned}
\text { SRISK }_{i t}^{e} & =\alpha+\sum_{k} \gamma_{k} X_{k t-1}+\rho_{1} \text { Misv }_{i t}+\rho_{2} \text { NConn }_{i t} \\
& +\lambda_{1} I M M R+\lambda_{2} I D+\lambda_{3} B I I+\lambda_{4} B I I I+\lambda_{5} S I I \\
& +\mu_{i}+\varepsilon_{i t}
\end{aligned}
$$

In order to control for major regulatory events in the banking and insurance industries we introduce time dummies for the four important milestones of the regulatory process: the first time dummy (1996 to 2002) marks the introduction of internal modelling for market risk (IMMR); the second period from January 2002 to June 2006 captures the effect of the introduction of the two 2002 Insurance Directives (ID); the third period from July 2006 until September 2008 catches the introduction of the Basel II agreement (BII); the fourth period (September 2008 onwards) proxies for the process of reforming Basel II in an attempt to reach agreement on Basel III; finally the last dummy controls for the introduction of Solvency II in January 2016 in the insurance industry.

We measures spillovers between banks and insurers looking at the impact of the number of significant connections between the two sectors, NConn. We use both internconnectedness in the mean returns and in the MES separately.

In order to address the issue of mixed frequencies in our data we aggregate the daily measures to their weekly medians. Moreover we include fixed effects to address for other time-invariant firm characteristics.

We run separate regressions for banks and insurance companies. In the sector "banks", we consider both commercial banks and diversified financials as classified in the previous Compustat categorization. Insurance companies consist of both Life and Non-life insurance types. The results are presented in the next section.

\section{Drivers of Systemic Risk}

Let us now analyze the drivers of the exposure to systemic risk as measured by SRISK: we will do this both for banking and for insurance. We perform similar regressions on SRISK for both groups to scrutinize the role of interconnectedness on the systemic relevance of banks compared to insurers.

When estimating the drivers of SRISK we employ three different measures of interconnectedness, one measure based on mean returns (Table 4), second a tail-centered measure based on the marginal expected shortfall (Table 5), and third a measure based on lead-lag relations in SRISK (Table ??) Here we report the results of the OLS panel regressions on the detrended SRISK. ${ }^{7}$

Starting with interconnectivity being measured on mean returns, in Table 4 we observe some commonalities but also differences across the banking and

\footnotetext{
${ }^{7}$ We have also performed IV estimations on a dynamic model with the third lag of SRISK as an instrument, which generate similar results and, hence, are not reported here.
} 
Table 4: SRISK in Banking and Insurance: Interconnectedness in Mean Returns (OLS)

\begin{tabular}{|c|c|c|c|c|c|c|}
\hline & (1) & (2) & (3) & (4) & (5) & (6) \\
\hline Detrended SRISK & & Banks & & & Insurers & \\
\hline Beta & $\begin{array}{c}-264.0 * * * \\
(43.55)\end{array}$ & $\begin{array}{c}-250.8^{* * *} \\
(40.86)\end{array}$ & $\begin{array}{c}-265.1 * * * \\
(43.84)\end{array}$ & $\begin{array}{c}-661.1^{* * *} \\
(120.6)\end{array}$ & $\begin{array}{c}-616.3^{* * *} \\
(114.3)\end{array}$ & $\begin{array}{c}-669.0^{* * *} \\
(120.9)\end{array}$ \\
\hline CISS & $\begin{array}{c}130.5^{* * *} \\
(37.56)\end{array}$ & $\begin{array}{c}174.5^{* * *} \\
(44.01)\end{array}$ & $\begin{array}{c}130.4^{* * *} * \\
(37.90)\end{array}$ & $\begin{array}{c}170.7 \\
(127.9)\end{array}$ & $\begin{array}{c}246.0^{* *} \\
(116.1)\end{array}$ & $\begin{array}{c}168.1 \\
(123.9)\end{array}$ \\
\hline Zscore & $\begin{array}{l}-2.747^{*} \\
(1.490)\end{array}$ & $\begin{array}{c}-3.001^{*} \\
(1.586)\end{array}$ & $\begin{array}{c}-2.760^{*} \\
(1.499)\end{array}$ & $\begin{array}{l}-4.245 \\
(3.978)\end{array}$ & $\begin{array}{l}-7.950 \\
(4.863)\end{array}$ & $\begin{array}{l}-4.308 \\
(3.754)\end{array}$ \\
\hline Market Return & $\begin{array}{c}5,048^{* * *} \\
(1,211)\end{array}$ & $\begin{array}{c}4,987 * * * \\
(1,199)\end{array}$ & $\begin{array}{c}5,043^{* * *} \\
(1,210)\end{array}$ & $\begin{array}{l}6,208^{*} \\
(3,099)\end{array}$ & $\begin{array}{l}6,000^{*} \\
(3,115)\end{array}$ & $\begin{array}{c}6,285^{*} \\
(3,087)\end{array}$ \\
\hline $\mathrm{LT}$ interest rates & $\begin{array}{c}1,104 * * * \\
(283.0)\end{array}$ & $\begin{array}{c}590.2^{* *} \\
(297.9)\end{array}$ & $\begin{array}{c}1,114^{* * *} \\
(282.9)\end{array}$ & $\begin{array}{c}859.1 \\
(1,547)\end{array}$ & $\begin{array}{l}-914.4 \\
(726.2)\end{array}$ & $\begin{array}{c}1,012 \\
(1,668)\end{array}$ \\
\hline Misval & $\begin{array}{c}-59.82^{* * *} \\
(22.16)\end{array}$ & $\begin{array}{c}-62.72^{* * *} \\
(20.73)\end{array}$ & $\begin{array}{c}-59.49 * * * \\
(22.06)\end{array}$ & $\begin{array}{l}-39.32 \\
(48.56)\end{array}$ & $\begin{array}{l}-59.59 \\
(44.53)\end{array}$ & $\begin{array}{l}-39.48 \\
(49.81)\end{array}$ \\
\hline Market Value & $\begin{array}{c}0.000431 \\
(0.00126)\end{array}$ & $\begin{array}{c}0.00114 \\
(0.00122)\end{array}$ & $\begin{array}{c}0.000335 \\
(0.00126)\end{array}$ & $\begin{array}{l}-0.00323 \\
(0.00217)\end{array}$ & $\begin{array}{l}-0.00145 \\
(0.00236)\end{array}$ & $\begin{array}{l}-0.00350 \\
(0.00214)\end{array}$ \\
\hline NConnRET & $\begin{array}{c}0.0105 \\
(0.0295)\end{array}$ & $\begin{array}{c}-0.260^{* *} \\
(0.109)\end{array}$ & $\begin{array}{l}-0.152^{*} \\
(0.0876)\end{array}$ & $\begin{array}{l}-0.201 \\
(0.722)\end{array}$ & $\begin{array}{l}-7.382 \\
(4.394)\end{array}$ & $\begin{array}{c}1.063 \\
(3.932)\end{array}$ \\
\hline Period 2 (1996-2002) & $\begin{array}{l}42.17^{* *} \\
(17.62)\end{array}$ & & $\begin{array}{l}27.67^{*} \\
(14.06)\end{array}$ & $\begin{array}{c}57.68 \\
(62.01)\end{array}$ & & $\begin{array}{c}45.27 \\
(64.49)\end{array}$ \\
\hline Period 3 (2002-2006) & $\begin{array}{c}96.96^{* * *} \\
(31.21)\end{array}$ & & $\begin{array}{c}84.58^{* * *} \\
(26.62)\end{array}$ & $\begin{array}{c}340.5^{* * *} * \\
(105.8)\end{array}$ & & $\begin{array}{c}387.4^{* * *} \\
(118.9)\end{array}$ \\
\hline Period 4 (2006-2008) & $\begin{array}{c}209.9^{* * * *} \\
(46.61)\end{array}$ & & $\begin{array}{c}194.4^{* * *} \\
(46.13)\end{array}$ & $\begin{array}{c}337.6^{* * * *} \\
(116.5)\end{array}$ & & $\begin{array}{c}387.6 * * * \\
(119.7)\end{array}$ \\
\hline Period 5 (2008-2015) & $\begin{array}{c}106.6 * * * \\
(38.62)\end{array}$ & & $\begin{array}{c}101.0^{* * * *} \\
(33.78)\end{array}$ & $\begin{array}{c}183.6 \\
(147.3)\end{array}$ & & $\begin{array}{c}237.2 \\
(159.3)\end{array}$ \\
\hline Period 6 (2016) & $\begin{array}{c}170.8^{* * *} \\
(39.01)\end{array}$ & & $\begin{array}{c}135.5^{* * *} * \\
(32.85)\end{array}$ & $\begin{array}{l}361.4^{*} \\
(176.7)\end{array}$ & & $\begin{array}{c}274.3 \\
(194.5)\end{array}$ \\
\hline 2.period $\backslash \#$ NConnRet & & $\begin{array}{l}0.194^{*} \\
(0.102)\end{array}$ & $\begin{array}{l}0.188^{*} \\
(0.100)\end{array}$ & & $\begin{array}{c}3.660 \\
(3.880)\end{array}$ & $\begin{array}{c}0.711 \\
(5.560)\end{array}$ \\
\hline 3.period $\backslash \#$ NConnRet & & $\begin{array}{l}0.283^{*} \\
(0.150)\end{array}$ & $\begin{array}{c}0.188 \\
(0.140)\end{array}$ & & $\begin{array}{c}13.04^{* * * *} \\
(4.711)\end{array}$ & $\begin{array}{l}-3.220 \\
(4.971)\end{array}$ \\
\hline 4.period $\backslash \# \mathrm{NConnRet}$ & & $\begin{array}{c}0.598^{* * *} \\
(0.150)\end{array}$ & $\begin{array}{l}0.212^{*} \\
(0.110)\end{array}$ & & $\begin{array}{l}9.647^{* *} \\
(4.570)\end{array}$ & $\begin{array}{l}-2.489 \\
(4.039)\end{array}$ \\
\hline 5.period $\backslash \# \mathrm{NConnRet}$ & & $\begin{array}{c}0.180 \\
(0.140)\end{array}$ & $\begin{array}{c}0.0960 \\
(0.116)\end{array}$ & & $\begin{array}{c}2.677 \\
(4.330)\end{array}$ & $\begin{array}{l}-3.356 \\
(2.999)\end{array}$ \\
\hline 6.period $\backslash \#$ NConnRet & & $\begin{array}{c}0.469^{* * *} \\
(0.127)\end{array}$ & $\begin{array}{c}0.296^{* *} \\
(0.121)\end{array}$ & & $\begin{array}{l}10.04^{* *} \\
(4.776)\end{array}$ & $\begin{array}{c}2.617 \\
(3.948)\end{array}$ \\
\hline Constant & $\begin{array}{c}126.8^{* * *} \\
(41.72)\end{array}$ & $\begin{array}{c}228.1^{* * *} \\
(55.47)\end{array}$ & $\begin{array}{c}139.1^{* * *} \\
(43.46)\end{array}$ & $\begin{array}{c}643.1^{* * *} \\
(226.3)\end{array}$ & $\begin{array}{c}898.3^{* * *} \\
(214.7)\end{array}$ & $\begin{array}{c}629.9^{* *} \\
(232.0)\end{array}$ \\
\hline Observations & 103,166 & 103,166 & 103,166 & 15,552 & 15,552 & 15,552 \\
\hline R-squared & 0.00777 & 0.00718 & 0.00777 & 0.0211 & 0.0192 & 0.0211 \\
\hline Number of firms & 173 & 173 & 173 & 29 & 29 & 29 \\
\hline $\mathrm{r} 2 \_\mathrm{b}$ & 0.00223 & 0.00560 & 0.00210 & 0.271 & 0.155 & 0.269 \\
\hline r2_o & 0.00290 & 0.00270 & 0.00289 & 0.0125 & 0.0106 & 0.0125 \\
\hline r2_w & 0.00789 & 0.00731 & 0.00794 & 0.0219 & 0.0200 & 0.0222 \\
\hline $\mathrm{p}$ & 0.0000 & 0.0000 & 0.0000 & 0.0000 & 0.0000 & 0.0000 \\
\hline $\mathrm{F}$ & 4.293 & 4.825 & 3.818 & 15.07 & 10.45 & 19.44 \\
\hline
\end{tabular}

Robust standard errors in parentheses

$* * * \mathrm{p}<0.01, * * \mathrm{p}<0.05, * \mathrm{p}<0.1$

a This table reports the results from the panel regressions of SRISK with fixed effects for the institutions belonging to the sector 'banks' or 'diversified institutions', and 'insurance'. Once detrended SRISK from its first lag, we regress the detrended SRISK on market Beta, interconnectedness on the mean returns (NConnRET), Zscore of default, Market Value and Market Misvaluation. We use 6 time dummies to identify the major steps of the banking and insurance regulations, as the introduction of internal models for market risks (Period 2), the introduction of Basel II (Period 3), the introduction of insurance 2002 regulation (Period 3), the guidelines for Basel III (Period 4), and the implementation of Solvency II (Period 6). We use the dummies with and without interaction with the interconnectedness measure. We also control for macro characteristics of the financial markets, using CISS measure of distress,

European equity market return, and long-term interest rates. 
Table 5: SRISK in Banking and Insurance Sectors: Interconnectedness in MES (OLS)

\begin{tabular}{|c|c|c|c|c|c|c|}
\hline Detrended SRISK & (1) & (2) & (3) & (4) & (5) & (6) \\
\hline & & Banks & & & Insurers & \\
\hline Beta & $\begin{array}{c}-263.8^{* * *} \\
(43.61)\end{array}$ & $\begin{array}{c}-253.8^{* * *} \\
(41.73)\end{array}$ & $\begin{array}{c}-264.4^{* * *} \\
(43.84)\end{array}$ & $\begin{array}{c}-672.0^{* * *} \\
(122.0)\end{array}$ & $\begin{array}{c}-661.1 * * * \\
(121.9)\end{array}$ & $\begin{array}{c}-701.6^{* * *} \\
(125.1)\end{array}$ \\
\hline CISS & $\begin{array}{c}114.7^{* * *} \\
(35.99)\end{array}$ & $\begin{array}{c}131.8^{* * *} \\
(37.34)\end{array}$ & $\begin{array}{c}111.1^{* * *} \\
(35.45)\end{array}$ & $\begin{array}{c}87.89 \\
(126.2)\end{array}$ & $\begin{array}{l}235.9 * * \\
(109.5)\end{array}$ & $\begin{array}{c}122.3 \\
(129.8)\end{array}$ \\
\hline Zscore & $\begin{array}{l}-2.852^{*} \\
(1.503)\end{array}$ & $\begin{array}{c}-3.127^{* *} \\
(1.516)\end{array}$ & $\begin{array}{l}-2.849^{*} \\
(1.458)\end{array}$ & $\begin{array}{l}-4.480 \\
(3.746)\end{array}$ & $\begin{array}{l}-4.936 \\
(4.024)\end{array}$ & $\begin{array}{l}-4.523 \\
(3.142)\end{array}$ \\
\hline Market Return & $\begin{array}{c}5,105^{* * *} * \\
(1,219)\end{array}$ & $\begin{array}{c}5,087^{* * *} * \\
(1,217)\end{array}$ & $\begin{array}{c}5,107 * * * \\
(1,222)\end{array}$ & $\begin{array}{c}6,414^{* *} \\
(3,108)\end{array}$ & $\begin{array}{l}6,281^{*} \\
(3,112)\end{array}$ & $\begin{array}{l}6,331^{*} \\
(3,095)\end{array}$ \\
\hline $\mathrm{LT}$ interest rates & $\begin{array}{c}1,249 * * * \\
(299.5)\end{array}$ & $\begin{array}{l}706.3^{* *} \\
(289.3)\end{array}$ & $\begin{array}{c}1,251^{* * *} \\
(306.4)\end{array}$ & $\begin{array}{c}1,140 \\
(1,583)\end{array}$ & $\begin{array}{c}-1,872^{* *} \\
(896.1)\end{array}$ & $\begin{array}{c}2,997 \\
(1,769)\end{array}$ \\
\hline Misval & $\begin{array}{c}-62.99^{* * *} \\
(22.37)\end{array}$ & $\begin{array}{c}-68.02^{* * *} \\
(21.77)\end{array}$ & $\begin{array}{c}-61.15^{* * *} \\
(22.20)\end{array}$ & $\begin{array}{l}-46.56 \\
(49.07)\end{array}$ & $\begin{array}{l}-65.91 \\
(53.16)\end{array}$ & $\begin{array}{l}-61.15 \\
(47.21)\end{array}$ \\
\hline Market Value & $\begin{array}{l}0.000423 \\
(0.00124)\end{array}$ & $\begin{array}{l}0.000484 \\
(0.00121)\end{array}$ & $\begin{array}{l}0.000112 \\
(0.00125)\end{array}$ & $\begin{array}{l}-0.00403^{*} \\
(0.00214)\end{array}$ & $\begin{array}{l}-0.00311 \\
(0.00225)\end{array}$ & $\begin{array}{r}-0.00421 * \\
(0.00228)\end{array}$ \\
\hline NconnMES & $\begin{array}{c}0.0667 * * * \\
(0.0159)\end{array}$ & $\begin{array}{c}-0.137^{* *} \\
(0.0641)\end{array}$ & $\begin{array}{l}-0.0731 \\
(0.0537)\end{array}$ & $\begin{array}{c}1.640^{* * * *} \\
(0.557)\end{array}$ & $\begin{array}{l}-0.0667 \\
(2.337)\end{array}$ & $\begin{array}{c}1.821 \\
(1.620)\end{array}$ \\
\hline Period 2 (1996-2002) & $\begin{array}{l}37.43^{* *} \\
(16.99)\end{array}$ & & $\begin{array}{l}16.42 \\
(12.73)\end{array}$ & $\begin{array}{l}33.29 \\
(61.77)\end{array}$ & & $\begin{array}{l}-41.49 \\
(56.71)\end{array}$ \\
\hline Period 3 (2002-2006) & $\begin{array}{c}92.74^{* * * *} \\
(30.83)\end{array}$ & & $\begin{array}{c}87.45^{* * *} \\
(24.43)\end{array}$ & $\begin{array}{c}315.7^{* * *} * \\
(101.2)\end{array}$ & & $\begin{array}{l}238.9^{* *} \\
(108.2)\end{array}$ \\
\hline Period 4 (2006-2008) & $\begin{array}{c}199.5^{* * *} \\
(45.48)\end{array}$ & & $\begin{array}{c}120.9^{* * *} \\
(33.98)\end{array}$ & $\begin{array}{c}301.5^{* *} \\
(110.9)\end{array}$ & & $\begin{array}{c}377.8^{* *} \\
(142.5)\end{array}$ \\
\hline Period 5 (2008-2015) & $\begin{array}{c}106.8^{* * *} * \\
(38.83)\end{array}$ & & $\begin{array}{c}87.10^{* * *} \\
(28.26)\end{array}$ & $\begin{array}{c}181.1 \\
(142.1)\end{array}$ & & $\begin{array}{l}456.5 * * \\
(187.6)\end{array}$ \\
\hline Period 6 (2016) & $\begin{array}{c}170.6^{* * * *} \\
(39.65)\end{array}$ & & $\begin{array}{c}147.8^{* * *} \\
(33.33)\end{array}$ & $\begin{array}{l}346.5^{* *} \\
(167.9)\end{array}$ & & $\begin{array}{l}472.9^{* *} \\
(216.9)\end{array}$ \\
\hline 2.period $\backslash \#$ NConnMES & & $\begin{array}{l}0.131^{* *} \\
(0.0547)\end{array}$ & $\begin{array}{l}0.118^{* *} \\
(0.0550)\end{array}$ & & $\begin{array}{c}0.501 \\
(2.218)\end{array}$ & $\begin{array}{c}2.307 \\
(2.403)\end{array}$ \\
\hline 3.period $\backslash \#$ NConnMES & & $\begin{array}{l}0.164 * * \\
(0.0676)\end{array}$ & $\begin{array}{c}0.0778 \\
(0.0545)\end{array}$ & & $\begin{array}{l}4.376^{*} \\
(2.358)\end{array}$ & $\begin{array}{c}2.688 \\
(2.345)\end{array}$ \\
\hline 4.period $\backslash \#$ NConnMES & & $\begin{array}{c}0.375^{* * *} * \\
(0.0848)\end{array}$ & $\begin{array}{c}0.263 * * * \\
(0.0611)\end{array}$ & & $\begin{array}{c}2.821 \\
(2.386)\end{array}$ & $\begin{array}{l}-0.255 \\
(1.917)\end{array}$ \\
\hline 5.period $\backslash \#$ NConnMES & & $\begin{array}{l}0.187^{* *} \\
(0.0818)\end{array}$ & $\begin{array}{c}0.125^{*} \\
(0.0680)\end{array}$ & & $\begin{array}{r}-0.0781 \\
(2.626)\end{array}$ & $\begin{array}{c}-3.482^{* *} \\
(1.606)\end{array}$ \\
\hline 6.period $\backslash \#$ NConnMES & & $\begin{array}{c}0.287^{* * *} \\
(0.0767)\end{array}$ & $\begin{array}{c}0.133^{*} \\
(0.0683)\end{array}$ & & $\begin{array}{c}2.437 \\
(2.662)\end{array}$ & $\begin{array}{c}0.173 \\
(1.879)\end{array}$ \\
\hline Constant & $\begin{array}{c}107.7^{* * *} \\
(40.87)\end{array}$ & $\begin{array}{c}225.5^{* * *} \\
(53.87)\end{array}$ & $\begin{array}{c}137.6^{* * *} \\
(45.41)\end{array}$ & $\begin{array}{c}611.2^{* * *} \\
(218.8)\end{array}$ & $\begin{array}{c}880.2^{* * *} \\
(201.9)\end{array}$ & $\begin{array}{l}492.8^{* *} \\
(216.3)\end{array}$ \\
\hline Observations & 103,166 & 103,166 & 103,166 & 15,552 & 15,552 & 15,552 \\
\hline $\mathrm{R}$-squared & 0.00793 & 0.00796 & 0.00814 & 0.0217 & 0.0218 & 0.0228 \\
\hline Number of firms & 173 & 173 & 173 & 29 & 29 & 29 \\
\hline r2_b & 0.00316 & 0.00489 & 0.00281 & 0.270 & 0.262 & 0.267 \\
\hline r2_o & 0.00308 & 0.00295 & 0.00311 & 0.0127 & 0.0134 & 0.0135 \\
\hline r2_w & 0.00806 & 0.00809 & 0.00831 & 0.0225 & 0.0226 & 0.0239 \\
\hline $\mathrm{p}$ & 0.0000 & 0.0000 & 0.0000 & 0.0000 & 0.0000 & 0.0000 \\
\hline $\mathrm{F}$ & 4.290 & 3.570 & 3.120 & 13.33 & 8.867 & 31.90 \\
\hline
\end{tabular}

Robust standard errors in parentheses

$* * * \mathrm{p}<0.01, * * \mathrm{p}<0.05, * \mathrm{p}<0.1$

a This table reports the results from the panel regressions of SRISK with fixed effects for the institutions belonging to the sector 'banks' or 'diversified institutions', and 'insurance'. Once detrended SRISK from its first lag, we regress the detrended SRISK on market Beta, interconnectedness on the Marginal Expected Shortfall, Zscore of default, Market Value and Market Misvaluation. We use 6 time dummies to identify the major steps of the banking and insurance regulations, as the introduction of internal models for market risks (Period 2), the introduction of Basel II (Period 3), the introduction of insurance 2002 regulation (Period 3), the guidelines for Basel III (Period 4), and the implementation of Solvency II (Period 6). We use the dummies with and without interaction with the interconnectedness measure. We also control for macro characteristics of the financial markets, using CISS measure of distress, European equity market return, and long-term interest rates. 
insurance industries. The systemic stress indicator CISS and market returns are drivers of SRISK in both industries, while Beta is moderating across both sectors. Differences do occur in the role of the long-term interest rate and the misvaluation, which are both significant in the case of banks but not for insurance. Interestingly, the long-term interest rate exerts a positive influence on SRISK and, thus, reduces the resiliency of banks while it has no significant effect on the insurance sector.

With regard to the policy regimes and the role of interconnectedness an interesting picture emerges. While each policy regime seems to add to SRISK in the banking sector, mainly period 2 (1996-2002), period 3 (2006-2008) and period 6 (2016) seem to add to SRISK in the insurance sector. Focusing on the period dummies, the regression results are consistent with the evolution we observed in the average sectors. We see a steady and dramatic decrease in banks' resiliency from late 1996s and all along the regulatory process of Basel. For the insurance sector, we observe a sharp and significant increase in SRISK around the implementation of the 2002 Insurance Directives and during the period of adoption of the IRB approach of Basel II. In the aftermath of the 2008 crisis, we cannot see a significant build-up of conditional capital shortfall until 2016, when again a significant increase can be observed. Actually, this increase is much stronger with the other two measures of interconnectedness as can be seen in Table 5 and Table ??. This increase of systemic risk exposure coincides with the introduction of Solvency II. While we are still short on observation for the implementation phase of Solvency II, this observation may appear worrisome and suggests that supervisors should keep exposure risk under close scrutiny.

Moreover, regressions (2) and (5) suggest that this increase in SRISK is largely related to increased interconnectedness between banks and insurance in precisely those periods.

The most important parameters are representing the sensitivity of systemic risk to the number of connections that an institution has with the other sector. In Table 4 we observe that, on average, systemic risk is higher when a firm is more interconnected with institutions from the other sector. This average effect in present in both sectors.

However, if we consider the interaction terms between interconnectedness and regulation periods, we see that systemic risk is higher for highly connected banks after the implementation of internal models for market risk, in 1996.

Next we report the results of the regressions of SRISK on the interconnectedness implied by the marginal expected shortfalls. Table 5 shows similar results as the previous Table 4 for banks. The level of interconnectedness with the insurance sector does increase the systemic risk exposure of the financial sector. We observe, however, that the impact of banks connections on the insurance sector is relatively weak. However the results are much stronger once we interact the number of interconnections with the regulation periods.

Measuring interconnectedness via SRISK across sectors (Table ??) again a similar picture emerges. Again the interaction terms between policy period and number of interconnections are particularly strong in the case of banks and only 
weakly in the case of insurance companies. ${ }^{8}$

Overall we can conclude that it seems that interconnectedness with insurers is weakening the banking system and the insurance sector. While we observe significant intereactions between measures of interconnectedness and the various milestone periods, those interactions are much weaker (i.e. less significant) in the case of insurance.

Finally, we look at the aggregate system and perform a VAR analysis on the major risk variables we have used before (Table 6). ${ }^{9}$ For all the three variables under analysis, looking at first differences in SRISK, Delta CoVaR and market beta, we observe that banks is leading the insurance sector in risk, particularly market risk.

Table 6: VAR between banks' and insurers' risk

\begin{tabular}{|c|c|c|c|c|c|c|}
\hline & (1) & $(2)$ & (3) & (4) & (5) & (6) \\
\hline & \multicolumn{2}{|c|}{ DSRISK } & \multicolumn{2}{|c|}{ Beta } & \multicolumn{2}{|c|}{ Delta CoVaR } \\
\hline & Banks & Insurers & Banks & Insurers & Banks & Insurers \\
\hline Banks, lag 1 & $\begin{array}{c}0.110^{* * *} \\
(0.0274)\end{array}$ & $\begin{array}{c}0.00816^{* *} \\
(0.00359)\end{array}$ & $\begin{array}{c}1.084^{* * *} \\
(0.0374)\end{array}$ & $\begin{array}{c}0.227 * * * \\
(0.0377)\end{array}$ & $\begin{array}{c}1.099 * * * \\
(0.0283)\end{array}$ & $\begin{array}{c}0.101^{* * *} \\
(0.0213)\end{array}$ \\
\hline Banks, lag 2 & $\begin{array}{c}-0.0619^{* *} \\
(0.0274)\end{array}$ & $\begin{array}{c}-0.000636 \\
(0.00360)\end{array}$ & $\begin{array}{c}-0.250^{* * *} \\
(0.0513)\end{array}$ & $\begin{array}{c}-0.153^{* * *} \\
(0.0516)\end{array}$ & $\begin{array}{c}-0.201 * * * \\
(0.0411)\end{array}$ & $\begin{array}{c}-0.0633^{* *} \\
(0.0310)\end{array}$ \\
\hline Banks, lag 3 & & & $\begin{array}{c}0.0956^{*} \\
(0.0516)\end{array}$ & $\begin{array}{c}0.0212 \\
(0.0519)\end{array}$ & $\begin{array}{l}-0.00184 \\
(0.0414)\end{array}$ & $\begin{array}{c}0.0167 \\
(0.0313)\end{array}$ \\
\hline Banks, lag 4 & & & $\begin{array}{l}-0.0956^{*} \\
(0.0510)\end{array}$ & $\begin{array}{l}-0.117^{* *} \\
(0.0513)\end{array}$ & $\begin{array}{r}-0.00117 \\
(0.0410)\end{array}$ & $\begin{array}{l}-0.0294 \\
(0.0309)\end{array}$ \\
\hline Banks, lag 5 & & & $\begin{array}{l}0.0719^{*} \\
(0.0377)\end{array}$ & $\begin{array}{c}0.0113 \\
(0.0379)\end{array}$ & $\begin{array}{c}0.0358 \\
(0.0273)\end{array}$ & $\begin{array}{l}-0.0222 \\
(0.0206)\end{array}$ \\
\hline Insurers, lag 1 & $\begin{array}{l}-0.182 \\
(0.208)\end{array}$ & $\begin{array}{c}0.105 * * * \\
(0.0273)\end{array}$ & $\begin{array}{l}-0.0172 \\
(0.0373)\end{array}$ & $\begin{array}{l}0.804^{* * *} \\
(0.0375)\end{array}$ & $\begin{array}{c}0.223^{* * *} \\
(0.0372)\end{array}$ & $\begin{array}{l}0.807 * * * \\
(0.0281)\end{array}$ \\
\hline Insurers, lag 2 & $\begin{array}{c}-0.428^{* *} \\
(0.209)\end{array}$ & $\begin{array}{c}-0.109 * * * \\
(0.0274)\end{array}$ & $\begin{array}{l}-0.0391 \\
(0.0481)\end{array}$ & $\begin{array}{l}-0.0297 \\
(0.0484)\end{array}$ & $\begin{array}{l}-0.0465 \\
(0.0466)\end{array}$ & $\begin{array}{l}-0.00125 \\
(0.0352)\end{array}$ \\
\hline Insurers, lag 3 & & & $\begin{array}{c}0.0229 \\
(0.0481)\end{array}$ & $\begin{array}{c}0.0494 \\
(0.0484)\end{array}$ & $\begin{array}{l}-0.0224 \\
(0.0465)\end{array}$ & $\begin{array}{c}0.0456 \\
(0.0351)\end{array}$ \\
\hline Insurers, lag 4 & & & $\begin{array}{l}0.0840^{*} \\
(0.0481)\end{array}$ & $\begin{array}{l}0.115^{* *} \\
(0.0484)\end{array}$ & $\begin{array}{l}-0.0437 \\
(0.0465)\end{array}$ & $\begin{array}{c}0.0423 \\
(0.0351)\end{array}$ \\
\hline Insurers, lag 5 & & & $\begin{array}{l}-0.0203 \\
(0.0372)\end{array}$ & $\begin{array}{c}0.0424 \\
(0.0374)\end{array}$ & $\begin{array}{c}-0.0733^{* *} \\
(0.0374)\end{array}$ & $\begin{array}{c}0.0857^{* * * *} \\
(0.0282)\end{array}$ \\
\hline Constant & $\begin{array}{c}2.388 \\
(2.250)\end{array}$ & $\begin{array}{l}-0.550^{*} \\
(0.295)\end{array}$ & $\begin{array}{c}0.0450^{* * *} \\
(0.00703)\end{array}$ & $\begin{array}{l}0.0141^{* *} \\
(0.00707)\end{array}$ & $\begin{array}{c}0.000306^{* * *} \\
(4.63 \mathrm{e}-05)\end{array}$ & $\begin{array}{l}6.07 \mathrm{e}-05^{*} \\
(3.50 \mathrm{e}-05)\end{array}$ \\
\hline Observations & 1,488 & 1,488 & 1,486 & 1,486 & 1,486 & 1,486 \\
\hline $\begin{array}{l}\text { Robust standar } \\
* * * \mathrm{p}<0.01, * *\end{array}$ & $\begin{array}{l}\text { errors in p } \\
<0.05, * \text { p }\end{array}$ & $\begin{array}{l}\text { rentheses } \\
0.1\end{array}$ & & & & \\
\hline
\end{tabular}

Indeed the Granger causality tests confirm this result (Table 7). We see

\footnotetext{
${ }^{8}$ The relatively weak significance most likely also relates to the fact that we have significantly less observations in the insurance sector relative to the banking sector.

${ }^{9}$ We do not report the results on Zscore, as no relation is implied by the VAR models we performed.
} 
that all variables, first difference in SRISK, Delta CoVaR and market beta, are affected by the aggregate risk of the other sector, without a clear indication of a leader-follower relationship. Only market beta show a strong leading impact from banks to insurance companies. But generally causation is two-ways.

Table 7: Granger Causality Test between Banks' and Insurers' Risk

\begin{tabular}{lllrr}
\hline Equation & Excluded & chi2 & df & pvalue \\
\hline DSRISK Banks & DSRISK Insurers & 5.384111 & 2 & $0.067742^{*}$ \\
DSRISK Insurers & DSRISK Banks & 5.167401 & 2 & $0.075494^{*}$ \\
& & & \\
Delta CoVaR Banks & Delta CoVaR Insurers & 53.60667 & 5 & $0.0000^{* * *}$ \\
Delta CoVaR Insurers & Delta CoVaR Banks & 34.21802 & 5 & $0.0000^{* * *}$ \\
& & & & \\
Beta Banks & Beta Insurers & 12.32099 & 5 & $0.030645^{* *}$ \\
Beta Insurers & Beta Banks & 47.46632 & 5 & $0.0000^{* * *}$ \\
\hline$* * * \mathrm{p}<0.01, * * \mathrm{p}<0.05, * \mathrm{p}<0.1$ & & & \\
\hline
\end{tabular}

${ }^{a}$ This table reports the results from the Granger causality test following the VAR models of sector-average SRISK (in its first difference), market Beta and Delta CoVaR between banks and insurance companies.

To spot changes over the six subperiods of our analysis, we perform the VARs in the sub-periods and report the Granger causality tests for each in Table 8.

Once we look at the different periods separately, we see a strong lead-lag patterns in term of contribution to systemic risk, Delta CoVaR (Figure 8). In nearly all periods, a shock in the banking Delta CoVaR causes a positive impact in the insurance CoVaR over several periods. Only in period 4 (2006-08) and in the last period 2016, we observe an opposite pattern: a shock in delta CoVaR in the insurance companies caused an increase in the systemic contribution of the banking system.

We see that a positive shock in the insurance sector often produces a reduction in SRISK in the banking sector and viceversa, and this is happening particularly in periods 2, 3 and 5 (Figure 6).

Finally, in terms of market Beta, we observe a clear pattern from banks to insurance companies (Figure 7). With the exception of the market crisis in 2007, and the last year after Solvency II, we see that a shock in the market beta in the banking sectors is producing an increase in the market risk in the insurance sector. It confirms the propagation of $\mathrm{CoVaR}$ shocks and the exception of the 2007-2008 years.

Overall the picture emerges that insurers are particularly affected by banking sector shocks in normal periods. In periods of stress, however, causation works both ways simultaneously. Only in 2016 a contribution from the insurance sector to the banking sector begins to emerge. Despite the few observations the effect already obtains statistical significance. 
Table 8: Granger causality test between banks' and insurers' risk, across subperiods

\begin{tabular}{|c|c|c|c|c|c|c|c|c|c|}
\hline \multicolumn{4}{|c|}{ SRISK } & \multicolumn{3}{|c|}{ Beta } & \multicolumn{3}{|c|}{ Delta CoVaR } \\
\hline Leader & chi2 & df & pvalue & chi2 & df & pvalue & chi2 & df & pvalue \\
\hline \multicolumn{10}{|c|}{ Period 1 (1987-1995) } \\
\hline Insurance & 2.6456 & 2 & 0.2664 & 0.9904 & 2 & 0.6094 & 6.9554 & 2 & $0.0309 * *$ \\
\hline Banks & 1.0369 & 2 & 0.5954 & 15.5918 & 2 & $0.0004^{* * *}$ & 0.9645 & 2 & 0.6174 \\
\hline \multicolumn{10}{|c|}{ Period 2 (1996-2001) } \\
\hline Insurance & 9.0763 & 2 & $0.0107 * *$ & 3.8141 & 3 & 0.2823 & 2.5375 & 2 & 0.2812 \\
\hline Banks & 3.1947 & 2 & 0.2024 & 7.9832 & 3 & $0.0464^{* *}$ & 29.8893 & 2 & $0.0000^{* * *}$ \\
\hline \multicolumn{10}{|c|}{ Period 3 (2002-2006) } \\
\hline Insurance & 6.0482 & 1 & $0.0139 * *$ & 6.7370 & 2 & $0.0344^{* *}$ & 3.0522 & 2 & 0.2174 \\
\hline Banks & 4.1191 & 1 & $0.0424^{* *}$ & 19.9511 & 2 & $0.0000^{* * *}$ & 16.8171 & 2 & $0.0002^{* * *}$ \\
\hline \multicolumn{10}{|c|}{ Period 4 (2006-2008) } \\
\hline Insurance & 3.8181 & 2 & 0.1482 & 11.3488 & 3 & $0.0100^{* * *}$ & 24.6843 & 2 & $0.0000^{* * *}$ \\
\hline Banks & 1.2159 & 2 & 0.5445 & 4.5872 & 3 & 0.2046 & 22.0649 & 2 & $0.0000^{* * *}$ \\
\hline \multicolumn{10}{|c|}{ Period 5 (2008-2015) } \\
\hline Insurance & 16.5559 & 6 & $0.0111^{* *}$ & 7.5890 & 4 & 0.1078 & 7.8638 & 5 & 0.1639 \\
\hline Banks & 11.5688 & 6 & $0.0723^{*}$ & 20.1252 & 4 & $0.0005^{* * *}$ & 38.2138 & 5 & $0.0000^{* * *}$ \\
\hline \multicolumn{10}{|c|}{ Period 6 (2016) } \\
\hline Insurance & 1.7019 & 2 & 0.4270 & 0.2327 & 2 & 0.8902 & 50.3228 & 2 & $0.0000^{* * *}$ \\
\hline Banks & 0.2982 & 2 & 0.8615 & 13.2681 & 2 & 0.0013 & 0.1563 & 2 & 0.9248 \\
\hline \multicolumn{10}{|c|}{$* * * \mathrm{p}<0.01,{ }^{* *} \mathrm{p}<0.05, * \mathrm{p}<0.1$} \\
\hline he results & VA] & & $\begin{array}{l}\text { or eact } \\
\text { oVaR }\end{array}$ & $\begin{array}{l}\text { eriod se } \\
\text { a banks } \\
\text { lels for } \\
\text { regulat }\end{array}$ & & $\begin{array}{l}n \text { secto } \\
\text { ance co }\end{array}$ & $\begin{array}{l}\text { ge SRIS } \\
\text { s. We d } \\
\text { the intr } \\
\text { ines for }\end{array}$ & & $\begin{array}{l}\text { first differ- } \\
\text { sh } 6 \text { periods } \\
\text { a of Basel II } \\
\text { I (Period 4), }\end{array}$ \\
\hline
\end{tabular}




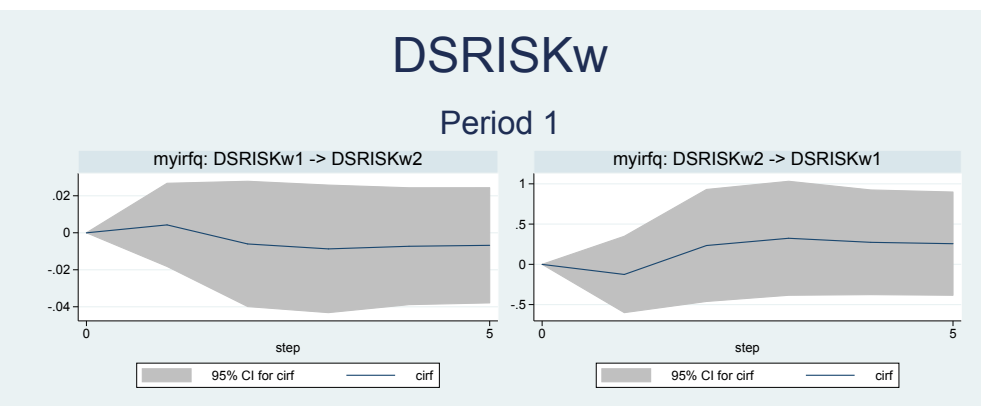

Period 2

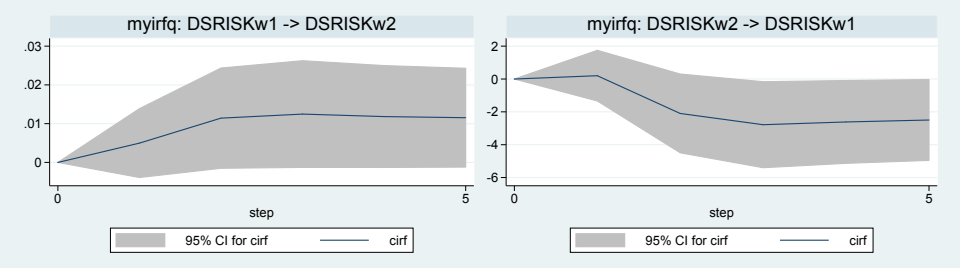

Period 3

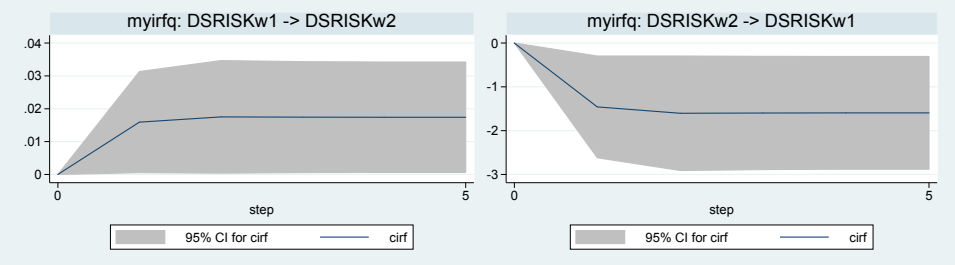

Period 4

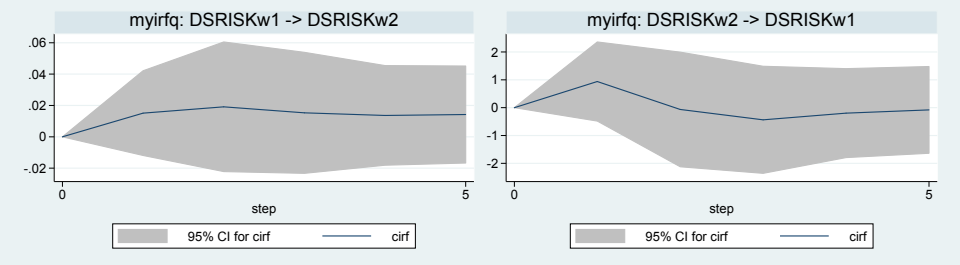

Period 5

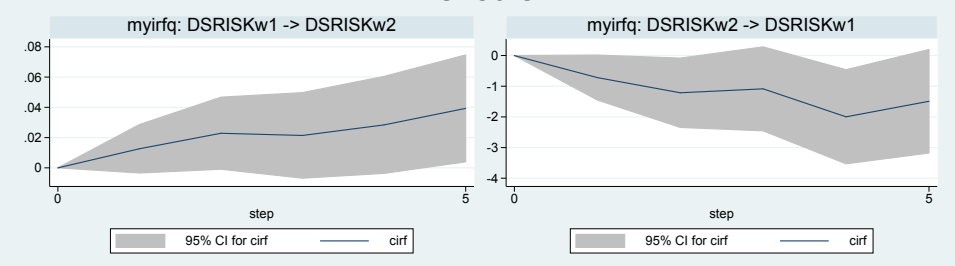

Period 6

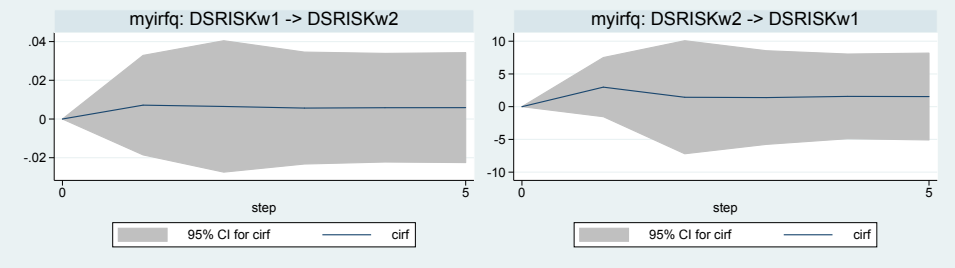

24

Figure 6: Cumulative Impulse-Response Functions of SRISK (first-difference) over the 6 Sub-periods.We distinguish: before Basel I (Period 1), the introduction of internal models for market risks (Period 2), the introduction of Basel II (Period 3), the introduction of insurance 2002 regulation (Period 3), the guidelines for Basel III (Period 4), and the implementation of Solvency II (Period 6). 

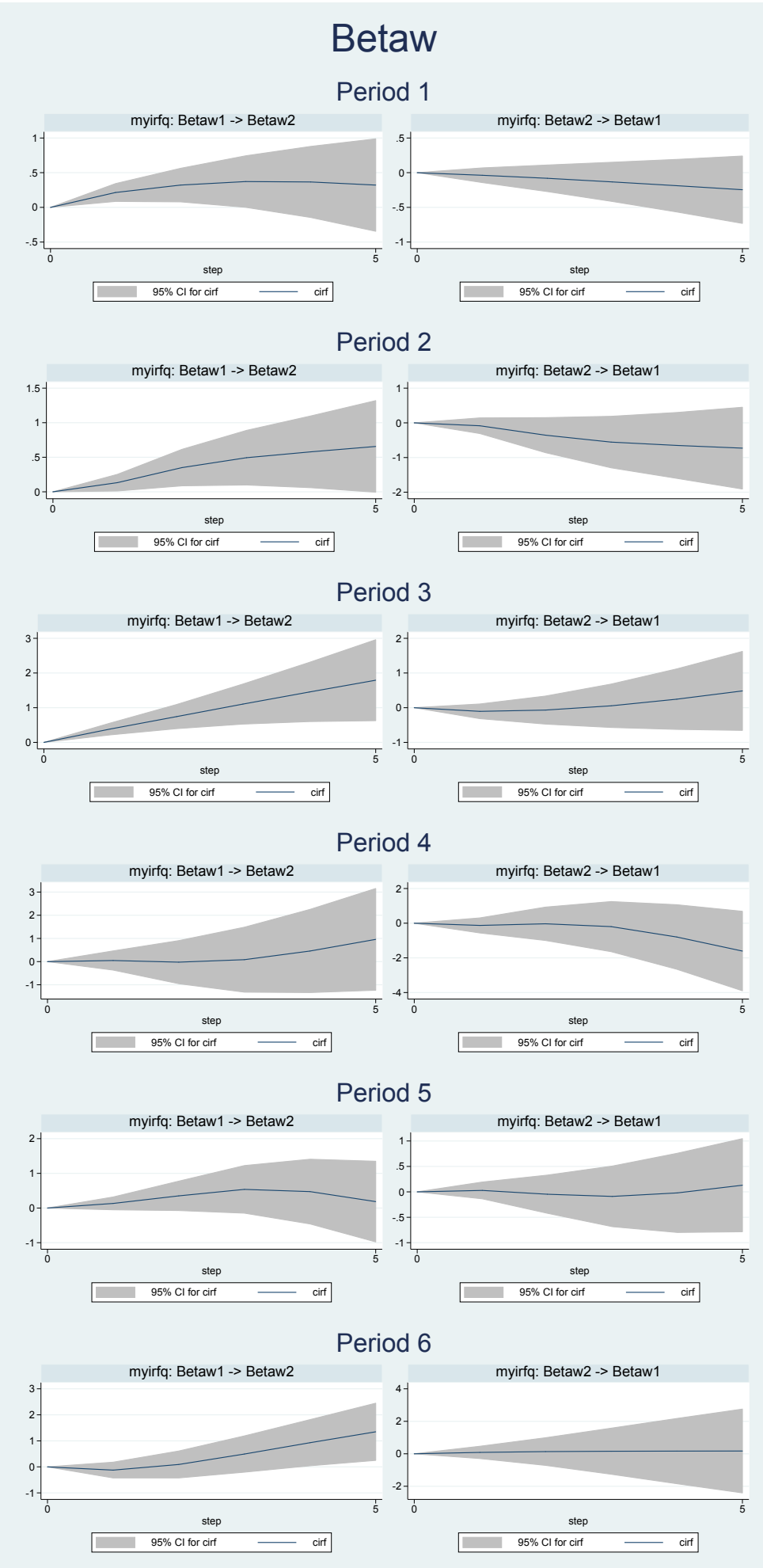

25

Figure 7: Cumulative impulse-response function of Beta over the 6 subperiods.We distinguish: before Basel I (Period 1), the introduction of internal models for market risks (Period 2), the introduction of Basel II (Period 3), the introduction of insurance 2002 regulation (Period 3), the guidelines for Basel III (Period 4), and the implementation of Solvency II (Period 6). 


\section{Delta_CoVaRw}
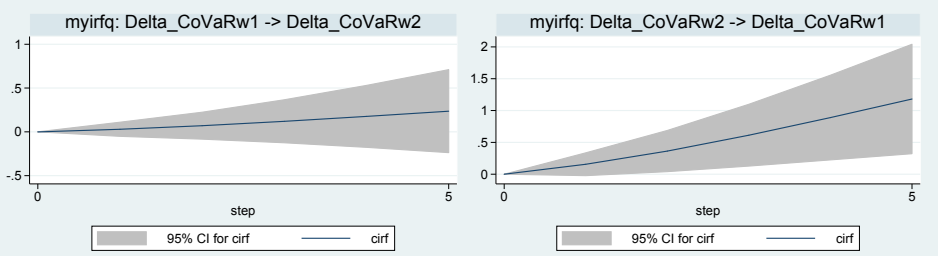

Period 2

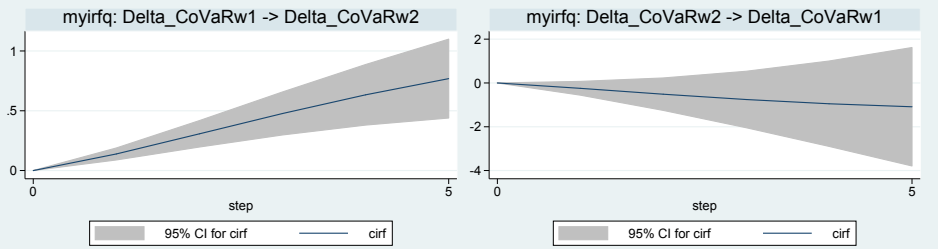

Period 3

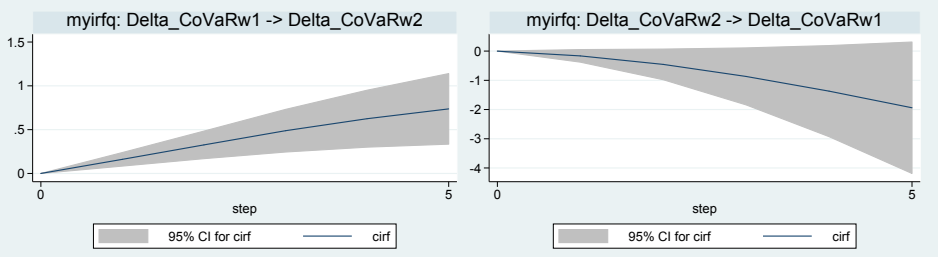

Period 4

myirfq: Delta CoVaRw1 $>$ > Delta_CoVaRw2
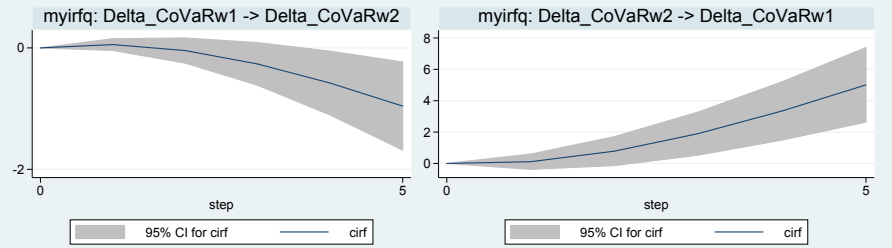

Period 5
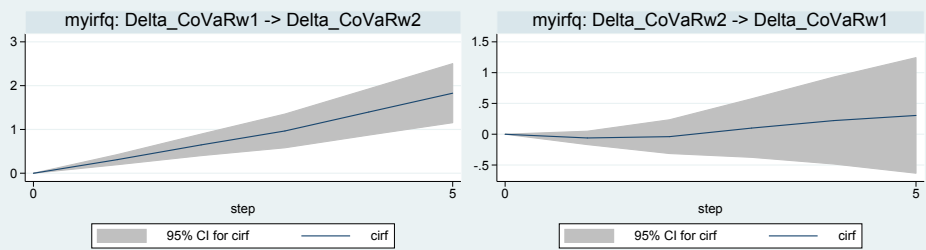

Period 6

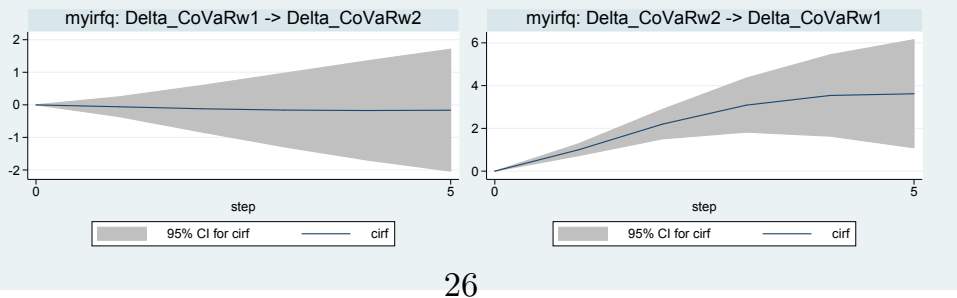

Figure 8: Cumulative impulse-response function of Delta CoVaR over the 6 sub-periods.We distinguish: before Basel I (Period 1), the introduction of internal models for market risks (Period 2), the introduction of Basel II (Period 3), the introduction of insurance 2002 regulation (Period 3), the guidelines for Basel III (Period 4), and the implementation of Solvency II (Period 6). 


\section{Conclusions}

This paper derives from an empirical investigation of the resiliency of the European financial system. It analyses the evolution of systemic risk measures for its various subsectors, banks and insurance companies in particular. This study allows us to trace the effects of the regulatory process in each subsector on the systemic risk exposure within that sector and its spillovers into other sectors. The insurance sector is particularly interesting, since its regulation was introduced with some time lag after corresponding regulation in the banking industry. In particular the regulation of capital followed earlier rules in the banking sector.

In this study we document a significant build-up of systemic risk in the European insurance sector that goes hand in hand with the implementation of the 2002 EU-Directives for life and property insurances, creating a new source of systemic risk: capital shortfall in the insurance sector.

Important drivers across sectors constitute their interconnections. It seems that the number of interconnections contributed to the build-up of systemic risk particularly after 1996 in the banking sector and after 2002 in the insurance sector.

Moreover, we identify important spill-overs from the banking industry to the insurance sector. Hitherto mainly systemic shocks to the banking sector were transmitted to the insurance sector but since 2016 we also see evidence in the other direction, i.e. from insurance to banking.

In light of our results and the experiences after the implementation of Basel II the introduction of Solvency II in January 2016 raises concerns about the capitalization of the insurance sector. There is a real danger that the lessons of the lack of capital of European banks during the Great Financial Crisis might be repeated in the insurance sector after negative economic shocks. Accordingly, European supervisors should be particularly concerned with the capitalization of large European insurance companies. Based on a completely different global sample of banks and insurance companies Malik and Xu (2017) reach a very similar conclusion about heightened need of supervision of globally active insurance companies, especially concerning their relations to banks. 


\section{References}

Acharya, V., R. Engle and M. Richardson (2012): Capital Shortfall: a new Approach to Ranking and Regulating Systemic Risks, AEA meeting.

Adrian, T. and M. K. Brunnermeier (2016): CoVaR. American Economic Review 106(7), 1705-1741.

Angelides P. (2011): Financial Crisis Inquiry Report. DIANE Publishing. p. 352 .

Baluch, F., S. Mutenga, and C. Parsons (2011): Insurance, Systemic Risk and the Financial Crisis. The Geneva Papers on Risk and Insurance Issues and Practice, 36(1), 126-163.

Baranoff, E. (2012): An Analysis of the AIG Case: Understanding Systemic Risk and Its Relation to Insurance. Journal of Insurance Regulation, 31, 243270 .

Benoit S., Colletaz G., Hurlin C. and C. Prignon (2013): A Theoretical and Empirical Comparison of Systemic Risk Measures, HEC Paris Research Paper No. FIN-2014-1030.

Behn, M., R. Haselmann, and V. Vig (2015): The Limits of Model-Based Regulation. SAFE Working Paper, Frankfurt, 75, 252.

Berdin, E., and M. Sottocornola (2014): Insurance Activities and Systemic Risk. Working Paper, (December), 152.

Billio, M., Getmansky, M., Lo, A. W., and Pelizzon, L. (2011): Econometric Measures of Systemic Risk in the Finance and Insurance Sectors. Working Paper, (August), 162.

Boyd, J. H. and Runkle D. E. (1993): Size and performance of banking firms: Testing the predictions of theory, Journal of Monetary Economics 31(1), 47-67.

Brownlees D. and R.F. Engle (2017): SRISK: A Conditional Capital Shortfall Measure of Systemic Risk, Review of Financial Studies 30(1), 48-79.

Chen, H., Cummins, J. D., Viswanathan, K. S., and Weiss, M. A. (2013): Systemic Risk and the Interconnectedness between Banks and Insurers: an Econometric Analysis. The Journal of Risk and Insurance, 81(3), 623-652.

Cummins, J. D., and Weiss, M. A. (2014): Systemic Risk and the U . S . Insurance Sector. Journal of Risk and Insurance, 81(3), 489-528. 
Cummins, J. D., and Boettner, J. E. (2011): Financial Sector Integration and Information Spillovers: Effects of Operational Risk Events on U.S. Banks and Insurers. Working Paper, September, 147.

Duran, M. A., and Lozano-Vivas, A. (2014): Risk shifting in the US banking system: An empirical analysis. Journal of Financial Stability, 13, 64-74.

Eling, M., and D, Pankoke (2016): Systemic Risk in the Insurance Sector: Review and Directions for Future Research, Risk Management and Insurance Review 19(2), 249-284.

Engle, R. (2002): Dynamic Conditional Correlation: A simple Class of Multivariate Generalized Autoregressive Conditional Heteroskedasticity Models, Journal of Business and Economic Statistic, vol. 20, p.339-350.

Fiordelisi, F., and D. Marques-Ibanez (2013): Is bank default risk systematic?, Journal of Banking and Finance 37 (6), 2000-2010.

Gehrig, T. and M.C. Iannino (2017): Did the Basel Process of Capital Regulation Enhance the Resiliency of European Banks?, CEPR-DP. 11920, London.

Gelos, G. and N. Valckx (2016): The insurance sector and systemic risk, VOX, CEPR's Policy Portal.

Glosten, L., R. Jagananthan and D. Runkle (1993): On the Relation between the Expected Value and the Volatility of Nominal Excess Returns on Stocks, Journal of Finance 48(5), 1779-1801.

Harrington, S. (2009): The Financial Crisis, Systemic risk, and the Future of Insurance Regulation. The Journal of Risk and Insurance, 76(4), 785-819.

IMF (2016): The insurance sector: Trends and systemic risk implications, in Global Financial Stability Report (April).

Malik, S. and T, Xu (2017): Interconnectedness of Global SystemicallyImportant Banks and Insurers, IMP Working Paper WP/17/210.

Neale, F., P. Drake, P. Schorno and E. Seman (2012): Insurance and Interconnectedness in the Financial Services Industry. Working Paper 135, August.

Weiss, G. and J. Mühlnickel (2014): Why do some insurers become systemically relevant? Journal of Financial Stability, 13, 95-117. 